\title{
Functional Role of the Interaction between Polysialic Acid and Extracellular Histone $\mathrm{H} 1$
}

\author{
Bibhudatta Mishra, ${ }^{1}$ Maren von der Ohe, ${ }^{1}$ Christian Schulze, ${ }^{1}$ Shan Bian, ${ }^{1}$ Tatjana Makhina, ${ }^{1}$ Gabriele Loers, ${ }^{1}$ \\ Ralf Kleene, ${ }^{1}$ and Melitta Schachner ${ }^{1,2}$ \\ ${ }^{1}$ Zentrum für Molekulare Neurobiologie, Universitätsklinikum Hamburg-Eppendorf, 20246 Hamburg, Germany, and ${ }^{2}$ Keck Center for Collaborative \\ Neuroscience and Department of Cell Biology and Neuroscience, Rutgers University, Piscataway, New Jersey 08854
}

Polysialic acid (PSA) is a large and highly negatively charged glycan that plays crucial roles in nervous system development and function in the adult. It has been suggested to facilitate cell migration, neurite outgrowth, and synaptic plasticity because its hydration volume could enhance flexibility of cell interactions. Evidence for receptors of PSA has so far been elusive. We now identified histone $\mathrm{H} 1$ as binding partner of PSA via a single-chain variable fragment antibody using an anti-idiotypic approach. Histone H1 directly binds to PSA as shown by ELISA. Surface biotinylation of cultured cerebellar neurons indicated an extracellular localization of histone H1. Immunostaining of live cerebellar neurons and Schwann cells confirmed that an extracellular pool of histone $\mathrm{H} 1$ colocalizes with PSA at the cell surface. Histone $\mathrm{H} 1$ was also detected in detergent-insoluble synaptosomal membrane subfractions and postsynaptic densities. When applied in vitro, histone $\mathrm{H} 1$ stimulated neuritogenesis, process formation and proliferation of Schwann cells, and migration of neural precursor cells via a PSA-dependent mechanism, further indicating that histone $\mathrm{H} 1$ is active extracellularly. These in vitro observations suggested an important functional role for the interaction between histone $\mathrm{H} 1$ and PSA not only for nervous system development but also for regeneration in the adult. Indeed, histone $\mathrm{H} 1$ improved functional recovery, axon regrowth, and precision of reinnervation of the motor branch in adult mice with femoral nerve injury. Our findings encourage investigations on the therapeutic potential of histone $\mathrm{Hl}$ in humans.

\section{Introduction}

Polysialic acid (PSA) — a long, linear polymer composed entirely of negatively charged sialic acid ( $5^{\prime}-N$-acetylneuraminic acid) in an unusual $\alpha 2,8$ linkage-belongs to a class of functionally important anionic glycans (for review, see Rutishauser, 2008). Because of its high negative charge, PSA is highly hydrated and has therefore been suggested to attenuate cellular interactions and increase cell motility (Mühlenhoff et al., 1998). In the mammalian brain, PSA is predominantly or probably exclusively attached to the protein backbone of the neural cell adhesion molecule (NCAM). So far, only neuropilin-2 has been identified in human dendritic cells as another carrier of PSA in mammals (Curreli et al., 2007). It remains to be shown, however, whether carriers other than NCAM express PSA in the brain.

PSA is associated with morphogenetic changes during developmental processes, such as cell migration, axonal growth, neu-

Received Dec. 23, 2009; revised July 12, 2010; accepted July 19, 2010.

M.S. is supported by the New Jersey Commission for Spinal Cord Research and is a consultant at the Center for Neuroscience at Shantou University Medical College, China. We are grateful to Drs. Alexandre Podtelejnikov and Matthias Mann (Protein Bioinformatics, Odense, Denmark) for protein sequencing, Dr. Ali Mehanna for help with the surgery, Emanuela Szpotowicz for excellent technical assistance, Dr. Nina Kurschat for the PSA-mimicking peptide, and Dr. Rita Gerardy-Schahn (Medizinische Hochschule Hannover, Hannover, Germany) for the PSA antibody and endoglycosidase N. The University Medical Center Hamburg-Eppendorf has filed a patent application for certain technology described in this paper.

Correspondence should be addressed to Melitta Schachner, Zentrum für Molekulare Neurobiologie, Universitätsklinikum Hamburg-Eppendorf, Martinistrasse 52, 20246 Hamburg, Germany. E-mail: melitta.schachner@ zmnh.uni-hamburg.de.

DOI:10.1523/JNEUROSCI.6407-09.2010

Copyright $\odot 2010$ the authors $\quad 0270-6474 / 10 / 3012400-14 \$ 15.00 / 0$ ritic branching, and synaptogenesis, and persists in the adult brain mainly in structures that display a high degree of functional plasticity (Kleene and Schachner, 2004; Rutishauser, 2008). During embryonic development, PSA is expressed abundantly by Schwann cells and axons in the peripheral nervous system. After peripheral nerve injury in adult rodents, PSA is upregulated in axons, Schwann cells, and skeletal muscle fibers (Carratù et al., 1993; Olsen et al., 1995; Mehanna et al., 2009). In vitro and in vivo functional assays using PSA mimetics and/or the bacterial homolog of PSA, colominic acid, indicate that PSA enhances myelination and regeneration of peripheral nerves (Jungnickel et al., 2009; Mehanna et al., 2009) and promotes spinal cord regeneration of mice (Papastefanaki et al., 2007; Marino et al., 2009; Mehanna et al., 2010).

The search for PSA binding partners has been hampered by low affinity of this glycan with protein receptors. It has been suggested that PSA interacts with brain-derived neurotrophic factor (BDNF) (Muller et al., 2000), heparan sulfate proteoglycans (Storms and Rutishauser, 1998), AMPA receptors (Vaithianathan et al., 2004), NR2B subunit-containing NMDA receptors (Hammond et al., 2006), and the gonadal hormone estradiol (Garcia-Segura et al., 1995). However, evidence for a direct interaction has so far been only provided for BDNF (Kanato et al., 2008). Here, we identified histone $\mathrm{H} 1$ as a novel interaction partner of PSA using the unconventional anti-idiotype approach and showed direct binding of histone $\mathrm{H} 1$ to PSA.

Histone $\mathrm{H} 1$ was discovered as a classical nuclear protein that is involved as a linker histone in the organization of nucleosomes 
that mediate DNA packing (Doenecke et al., 1997). It is also present extranuclearly (Parseghian and Luhrs, 2006) and even extracellularly at the surface of several cell types (Watson et al., 1995; Brix et al., 1998; Henriquez et al., 2002).

Here, we show that histone $\mathrm{H} 1$ is present extracellularly at the cell surface of cerebellar neurons and Schwann cells and that extracellular histone $\mathrm{H} 1$ has a beneficial effect on neural precursor cell migration, neurite outgrowth, as well as Schwann cell proliferation and process elongation. Increased functional recovery and preferential motoneuron reinnervation after peripheral nerve injury elicited by histone $\mathrm{H} 1$ indicates its importance in regeneration in vivo.

\section{Materials and Methods}

Antibodies and reagents. Rabbit polyclonal antibody against human histone H1 (Santa Cruz Biotechnology), mouse monoclonal antibody AE-4 against histone H1 (Millipore), horseradish peroxidase (HRP)conjugated NeutrAvidin (Thermo Fisher Scientific), HNK-1 antibody 412 (Kruse et al., 1984), and mouse antibody G3G4 against 5-bromo-2' deoxyuridine (BrdU) (Developmental Studies Hybridoma Bank) were used. Mouse monoclonal IgG2a antibody 735 against PSA (Frosch et al., 1985 ) and endoglycosidase N were kind gifts from Dr. Rita GerardySchahn (Zentrum Biochemie, Zelluläre Chemie, Medizinische Hochschule, Hannover, Germany). Secondary antibodies were purchased from Dianova. Histone H1 (14-155), H2A (14-493), H2B (14-491), H3 (14-411), and H4 (14-412) were purchased from Millipore, and glyceraldehyde-3-phosphate dehydrogenase (GAPDH), colominic acid (average molecular weight: $\sim 12 \mathrm{kDa}$ ), chondroitin sulfate A (average molecular weight: $\sim 20 \mathrm{kDa}$ ) and $\mathrm{C}$ (average molecular weight: $\sim 63$ $\mathrm{kDa}$ ), and heparin (average molecular weight: $\sim 3 \mathrm{kDa}$ ) were from Sigma-Aldrich.

Propagation of phage library. The "Griffin.1" phage scFv library (Griffiths et al., 1994) consisting of $\sim 10^{6}$ individual synthetic human scFv antibodies cloned into the phagemid pHEN2 was a kind gift from Dr. Greg Winter (Medical Research Council Center for Protein Engineering, Cambridge, UK). The suppressor Escherichia coli strain TG1 (K12, supE, hsdD5/F', thi, $\Delta\left(\right.$ lac $^{-}$pro $)$, traD36, proA $+B+$, lacl $^{9}$, lacZ $\left.\Delta M 15\right)$ was infected with the Griffin.1 phage scFv library and grown in 2TY medium ( $16 \mathrm{~g} / \mathrm{L}$ tryptone, $10 \mathrm{~g} / \mathrm{L}$ yeast extract, $5 \mathrm{~g} / \mathrm{L} \mathrm{NaCl}$ ) supplemented with 100 $\mu \mathrm{g} / \mathrm{ml}$ ampicillin and $1 \%$ glucose. When reaching exponential growth $\left(\mathrm{OD}_{600}=0.5\right), 2 \times 10^{11} \mathrm{M} 13 \mathrm{~K} 07$ helper phages (GE Healthcare) were applied to $25 \mathrm{ml}$ cultures (corresponding to $\sim 1 \times 10^{10}$ bacteria). After incubation for $30 \mathrm{~min}$ at $37^{\circ} \mathrm{C}$, the infected bacteria were centrifuged for $10 \mathrm{~min}$ at $3300 \times \mathrm{g}$, and the pellet was incubated in 2YT medium supplemented with $100 \mu \mathrm{g} / \mathrm{ml}$ ampicillin and $25 \mu \mathrm{g} / \mathrm{ml}$ kanamycin overnight at $30^{\circ} \mathrm{C}$. The bacteria were pelleted at $10,800 \times g$ for $10 \mathrm{~min}$ at $4^{\circ} \mathrm{C}$, and $0.2 \mathrm{vol}$ of polyethylene glycol (PEG)/ $\mathrm{NaCl}(20 \%$ PEG6000 in $2.5 \mathrm{M}$ $\mathrm{NaCl}$ ) was added to the resulting supernatant containing the phages. After incubation on ice for $1 \mathrm{~h}$, phages were pelleted by centrifugation at $10,800 \times g$ for $30 \mathrm{~min}$, and the resulting pellet was resuspended in $40 \mathrm{ml}$ of $\mathrm{H}_{2} \mathrm{O}$ and $8 \mathrm{ml}$ of PEG/ $\mathrm{NaCl}$ and incubated for $20 \mathrm{~min}$, all at $4^{\circ} \mathrm{C}$. After centrifugation at $10,800 \times g$ for $30 \mathrm{~min}$, the phage pellet was resuspended in $5 \mathrm{ml}$ of PBS $\left(8.1 \mathrm{mM} \mathrm{Na} \mathrm{NPO}_{4}, 1.74 \mathrm{~mm}\right.$ $\mathrm{NaH}_{2} \mathrm{PO}_{4}, 0.15 \mathrm{M} \mathrm{NaCl}, \mathrm{pH}$ 7.5).

Selection of PSA-mimicking anti-idiotypic scFv antibodies. The PSA IgG2a antibody, diluted in $4 \mathrm{ml}$ of PBS $(100 \mu \mathrm{g} / \mathrm{ml})$, was incubated in immunotubes (Maxisorb; Nalgene Nunc International) overnight at $4^{\circ} \mathrm{C}$. After three washes with PBS, the tubes were blocked with $2 \%$ skim milk (Frema Reform, DE-VAU-GE) in PBS (MPBS) for $2 \mathrm{~h}$ at room temperature. For preabsorption of unspecifically binding phages, an immunotube was blocked with $2 \%$ MPBS and incubated with $4 \mathrm{ml}$ of PBS containing $\sim 4 \times 10^{13}$ phages, $2 \mathrm{mg}$ of mouse serum (Sigma-Aldrich) and $24 \mu \mathrm{g}$ of mouse IgG2a (Cymbus Biotechnology) for $1 \mathrm{~h}$ at room temperature. The preincubated phage suspension was transferred to the immunotube coated with PSA antibody and incubated at room temperature for $30 \mathrm{~min}$ on a head-over-top rotator and $1.5 \mathrm{~h}$ without agitation. After incubation, the tube was washed 20 times with PBS containing $0.1 \%$ Tween 20 , followed by 20 washes with PBS at room temperature.
Bound phages were eluted at room temperature with $1 \mathrm{ml}$ of $100 \mathrm{~mm}$ triethylamine and immediately neutralized with $0.5 \mathrm{ml}$ of $1 \mathrm{M} \mathrm{Tris} / \mathrm{HCl}$, $\mathrm{pH}$ 7.4. The eluted phages were used to infect exponentially growing $E$. coli TG1 cells, and infected bacteria were grown overnight at $30^{\circ} \mathrm{C}$ on TYE plates ( $15 \mathrm{~g} / \mathrm{L}$ agar, $10 \mathrm{~g} / \mathrm{L}$ yeast extract, $8 \mathrm{~g} / \mathrm{L} \mathrm{NaCl}$ ) containing $100 \mu \mathrm{g} / \mathrm{ml}$ ampicillin and $1 \%$ glucose. After four rounds of selection, individual clones were analyzed by phage ELISA.

Phage ELISA. The binding specificity of phages that expressed potential PSA-mimicking anti-idiotypic scFv antibodies was tested by phage ELISA. Microtiter plates (Maxisorb; Nalgene Nunc International) were coated overnight at $4^{\circ} \mathrm{C}$ with $50 \mu$ l of purified PSA antibody in PBS (100 $\mu \mathrm{g} / \mathrm{ml}$ ) per well. All following steps were performed at room temperature. The plates were blocked with $2 \%$ MPBS. As negative controls, $50 \mu \mathrm{l}$ of nonimmune mouse serum $(500 \mu \mathrm{g} / \mathrm{ml})$ and nonimmune IgG2a (25 $\mu \mathrm{g} / \mathrm{ml}$ ) were used. After blocking with $2 \%$ MPBS for $1 \mathrm{~h}$ at room temperature, plates were incubated with bacterial supernatants containing phages that expressed potential PSA-mimicking anti-idiotypic scFv antibodies. After six washes with PBS, bound phages were detected using a HRP-conjugated monoclonal antibody against M13 phage (GE Healthcare) and 2,2'-azino-bis(3-ethylbenzthiazoline-6-sulfonic acid) as substrate. Absorption at $405 \mathrm{~nm}$ was measured.

DNA sequencing and truncation of the scFv linker region. The sequences of phage clones that expressed potential PSA-mimicking anti-idiotypic scFv antibodies were determined with the primers LMB3 (5'-CAG GAA ACA GCT ATG AC- $3^{\prime}$ ) and fdSeq1 (5'-GAA TTT TCT GTA TGA GG$3^{\prime}$ ) using a model 377 DNA Sequencer from Applied Biosystems. For truncation of the linker region from 14 aa (SSGGGGSGGGGSGG) to 5 aa (SSGGG), pHEN2-derived plasmid DNA deriving from phages that expressed potential PSA-mimicking anti-idiotypic scFv antibodies were subjected to PCR using the primers 5' -CAG CCG GCC ATG GCC CAG GTG-3' and 5'-GAG TCA CCG TGC ACT GCC TCC ACC ACT CGA GAC GGT GAC CAG GGT-3'. The PCR product and the $\mathrm{pHEN} 2$ phagederived plasmids were cut with NcoI and ApaL1 and ligated.

Production, purification, and FPLC analysis of scFv antibodies. To produce soluble scFv antibodies, the nonsuppressor strain HB2151 [K12, ara, thi/ $F^{\prime}$, pro $A+B+, \Delta\left(\right.$ lac ${ }^{-}$pro $)$, lacl ${ }^{q}$, lacZ $\left.\Delta M 15\right]$ was infected with phages that encode PSA-mimicking anti-idiotype scFv antibodies. An amber stop codon in the pHEN2 sequence between the scFv gene and the M13 minor coat protein III gene allowed the expression of his- and myc-tagged scFv antibodies. Infected bacteria were grown at $37^{\circ} \mathrm{C}$ in $\mathrm{LB}$ medium containing $0.1 \%$ glucose and $100 \mu \mathrm{g} / \mathrm{ml}$ ampicillin. At $\mathrm{OD}_{600}$ $0.8-0.9$, production of $\mathrm{scFv}$ antibodies was induced by addition of isopropyl- $\beta$-D-thiogalactopyranoside at a final concentration of $1 \mathrm{~mm}$. After an overnight incubation at $30^{\circ} \mathrm{C}$, culture supernatants were concentrated by ultrafiltration and applied to Ni-NTA agarose beads (QIAGEN) that had been equilibrated with $50 \mathrm{~mm}$ phosphate buffer, $\mathrm{pH}$ $7.5,300 \mathrm{~mm} \mathrm{NaCl}$, and $10 \mathrm{~mm}$ imidazole. After an overnight incubation at $4^{\circ} \mathrm{C}$, the beads were centrifuged at $2500 \times g$ for $5 \mathrm{~min}$ and washed with 50 mu phosphate buffer, $\mathrm{pH} 7.5,300 \mathrm{~mm} \mathrm{NaCl}$, and $20 \mathrm{~mm}$ imidazole. The scFv antibodies were eluted by incubating beads with $50 \mathrm{~mm}$ phosphate buffer, pH 7.5, $300 \mathrm{~mm} \mathrm{NaCl}$, and $250 \mathrm{~mm}$ imidazole for $30 \mathrm{~min}$ at $4^{\circ} \mathrm{C}$, and the eluted $\mathrm{scFv}$ antibodies were concentrated by centrifugation in Centricon-5 tubes (Millipore) and diluted in PBS.

To separate monomeric forms of scFv antibodies from dimeric or oligomeric forms, purified scFv antibodies were subjected to FPLC using a Superdex-75 column (diameter, $16 \mathrm{~mm}$; length, $40 \mathrm{~cm}$ ) and a BioCAD system (Applied Biosystems) at a flow rate of $1 \mathrm{ml} / \mathrm{min}$ and detection at $280 \mathrm{~nm}$.

ELISA using $s c F v$ antibodies. The specificity of the potential PSAmimicking anti-idiotypic scFv antibodies was tested by competition ELISA in 96-well microtiter plates (Nalgene Nunc International) coated with $100 \mu \mathrm{l}$ of PSA antibody $\left(100 \mu \mathrm{g} / \mathrm{ml}\right.$ PBS) overnight at $4^{\circ} \mathrm{C}$. All following steps were performed at room temperature. After blocking the plates with $2 \%$ MPBS, purified scFv antibodies supplemented with $2 \%$ skimmed milk were added to the plates and incubated for 1.5 h. For competition, colominic acid, chondroitin sulfate A and C, or heparin were preincubated with the coated antibody before addition of scFv antibodies. After washing three times with $0.05 \%$ Tween 20 in PBS and three times with PBS, anti-myc tag antibody (Santa Cruz Biotechnology) 
was added and incubated for $1 \mathrm{~h}$ to detect binding of the myc-tagged scFv antibodies. The wells were washed again and incubated with HRP-conjugated secondary antibody for $1 \mathrm{~h}$. Binding was detected using 2,2'-azino-bis(3-ethylbenzthiazoline-6-sulfonic acid) as substrate and measuring absorption at $405 \mathrm{~nm}$.

Surface plasmon resonance. As an alternative method to test the specificity of the potential PSA-mimicking anti-idiotypic scFv antibodies, surface plasmon resonance was performed. The PSA antibody was immobilized on a CM5 sensor chip (BIAcore). Purified anti-idiotypic antibodies in PBS were injected and sensorgrams were recorded using a BIAcore 3000 instrument. For competition, $5 \mu \mathrm{M} \mathrm{scFv}$ antibody was mixed with the competitor before injection.

Preparation of crude membrane fraction, synaptosomes, membraneassociated proteins, and postsynaptic densities. Brains from postnatal $(7 \mathrm{~d}$ of age) or adult (12-16 weeks of age) C57BL/6J mice were homogenized in homogenization buffer $\left[0.32 \mathrm{M}\right.$ sucrose, $1 \mathrm{~mm} \mathrm{CaCl}_{2}, 1 \mathrm{mM} \mathrm{MgCl}_{2}, 5$ $\mathrm{mm}$ Tris/ $\mathrm{HCl}, \mathrm{pH} 7.5$, and protease inhibitor (Roche)]. All steps were performed on ice or at $4^{\circ} \mathrm{C}$. The homogenate was centrifuged for $10 \mathrm{~min}$ at $17,000 \times g$. The pellet was resuspended in homogenization buffer, applied to a 1.2, 1.0, and $0.8 \mathrm{~m}$ sucrose step gradient, and centrifuged for $2 \mathrm{~h}$ at $100,000 \times \mathrm{g}$. The material from the 1.0/1.2 $\mathrm{M}$ sucrose interface was collected, diluted, and pelleted by centrifugation for 20 $\min$ at $17,000 \times g$. The pellet enriched in synaptosomal membranes was resuspended in PBS containing 1\% Triton X-100 and incubated for $30 \mathrm{~min}$. This fraction was taken as a detergent-solubilized synaptosomal membrane subfraction.

For the preparation of membrane-associated proteins, brains were homogenized in $4 \mathrm{ml}$ of TNE buffer ( $25 \mathrm{~mm}$ Tris-HCl, pH 7.5, $150 \mathrm{~mm}$ $\mathrm{NaCl}, 5 \mathrm{~mm}$ EDTA). The homogenates were centrifuged at $1000 \times \mathrm{g}$ for $10 \mathrm{~min}$, and the resulting supernatant was centrifuged at $100,000 \times g$ for $30 \mathrm{~min}$. The pellet was resuspended in $2 \mathrm{ml}$ of TNE buffer and adjusted to $150 \mathrm{~mm} \mathrm{NaHCO}_{3}, \mathrm{pH}$ 11.5. After incubation for $30 \mathrm{~min}$, the sample was subjected to centrifugation at $100,000 \times g$ for $30 \mathrm{~min}$. The resulting supernatant was taken as a subfraction enriched in membrane-associated proteins.

Postsynaptic densities (PSDs) were prepared according to a described protocol (Cohen et al., 1977).

Affinity chromatography with PSA-mimicking anti-idiotypic scFv antibodies. The fraction containing membrane-associated proteins was first run over a Sepharose 4B column (GE Healthcare) and then over a column with $3.2 \mathrm{mg}$ of purified $\mathrm{scFv}$ antibodies immobilized on $2 \mathrm{ml}$ of $\mathrm{CNBr}$-activated Sepharose $4 \mathrm{~B}$ (GE Healthcare) overnight at $4^{\circ} \mathrm{C}$ at a flow rate of $0.2 \mathrm{ml} / \mathrm{min}$. After washing the column with $15 \mathrm{ml}$ of PBS $(0.3$ $\mathrm{ml} / \mathrm{min}$ ), bound proteins were eluted with $200 \mathrm{~mm}$ glycine $/ 500 \mathrm{~mm} \mathrm{NaCl}$, $\mathrm{pH} 2.7(0.3 \mathrm{ml} / \mathrm{min})$. The eluted fractions were collected and neutralized immediately with $1 \mathrm{~m}$ Tris/ $\mathrm{HCl}, \mathrm{pH}$ 8.8. After ultrafiltration using Centricon-5 tubes (Millipore), the proteins were analyzed by SDSPAGE, silver staining, and mass spectrometry.

Western blot analysis, silver staining, mass spectrometry, and cell surface biotinylation. Western blot analysis, silver staining, mass spectrometry, and cell surface biotinylation were performed as described in detail (Makhina et al., 2009).

ELISA with histone H1. Binding of histone $\mathrm{H} 1$ to PSA was analyzed by ELISA. The 384-well flat-bottom microtiter plates (Corning) were coated in triplicate with $25 \mu \mathrm{l}$ of histone H1 or GAPDH ( $10 \mu \mathrm{g} / \mathrm{ml}$ in PBS) or PBS alone at $4^{\circ} \mathrm{C}$ overnight. All following steps were performed at room temperature. After blocking with 1\% BSA for $1 \mathrm{~h}$, the wells were washed three times with PBS containing 0.05\% Tween 20 (PBST). Wells were incubated with increasing concentrations of soluble colominic acid for $1 \mathrm{~h}$. After washing five times with PBST and two times with PBS, $25 \mu \mathrm{l}$ of PSA antibody $(5 \mu \mathrm{g} / \mathrm{ml})$ were added to each well. After incubation for $1 \mathrm{~h}$, the plates were washed six times with PBST and two times with PBS. The wells were incubated with HRP-conjugated secondary mouse antibody for $1 \mathrm{~h}$ and washed five times with PBST and two times with PBS. Binding was visualized by incubating wells with $50 \mu \mathrm{l}$ of 0.5 $\mathrm{mg} / \mathrm{ml} o$-phenylenediamine dihydrochloride (Thermo Fisher Scientific) for $2-5 \mathrm{~min}$. The reaction was stopped by addition of $50 \mu \mathrm{l}$ of 2.5 $\mathrm{M} \mathrm{H}_{2} \mathrm{SO}_{4}$ and quantified using an ELISA reader at $490 \mathrm{~nm}$ and the software KCjunior (Bio-Tek).
Analysis of neurite outgrowth from cultured cerebellar neurons and analysis of process length and proliferation of cultured Schwann cells. Primary cultures of cerebellar neurons or Schwann cells were prepared from cerebellum or dorsal root ganglia of 7-d-old C57BL/6J mice as described previously (Mehanna et al., 2009). In brief, 48-well plates were coated with $0.01 \%$ poly-L-lysine (PLL) overnight at $4^{\circ} \mathrm{C}$, washed twice with water, air-dried, and coated overnight with histone $\mathrm{H} 1$ or laminin at a concentration of $10 \mu \mathrm{g} / \mathrm{ml}$ at $4^{\circ} \mathrm{C}$. The plates were washed twice with PBS, and Schwann cells or cerebellar neurons were seeded at a density of $5 \times 10^{4}$ or $1 \times 10^{5}$ cells per well in $250 \mu$ l of corresponding serum-free culture medium. For antibody blocking experiments, PSA antibody or a rabbit polyclonal antibody against histone $\mathrm{H} 1$ were added to the wells at a concentration of 40 or $10 \mu \mathrm{g} / \mathrm{ml} 1 \mathrm{~h}$ after cells had been seeded. Similarly, soluble histone $\mathrm{H} 1$, soluble colominic acid, and/or endoglycosidase $\mathrm{N}$ were added to the culture at a concentration of 10,10 , or $4.8 \mu \mathrm{g} / \mathrm{ml}$, respectively. After maintaining for $24 \mathrm{~h}$ at $37^{\circ} \mathrm{C}$, cells were fixed with $2.5 \%$ glutaraldehyde and stained with $1 \%$ methylene blue/toluidine blue in $1 \%$ borax.

Morphological quantification of neurite or process lengths was done as described previously (Mehanna et al., 2009). Schwann cell processes and neurites of cerebellar neurons with a length of at least one cell body diameter were counted, and total neurite or process length per cell was determined by counting 50 cells in each of two wells per experiment. Schwann cell proliferation assay was performed as described previously (Mehanna et al., 2009), and $\sim 1000$ cells for each experimental value were counted.

Immunostaining of live Schwann cells and cerebellar neurons. Schwann cells or cerebellar neurons were seeded at a density of $2 \times 10^{5}$ on $12 \mathrm{~mm}$ glass coverslips pretreated with $0.01 \%$ PLL. After $20 \mathrm{~h}$ at $37^{\circ} \mathrm{C}$, cells were washed three times with the corresponding serum-free culture medium containing 1\% BSA and incubated with the antibodies against PSA and histone $\mathrm{H} 1$ for $20 \mathrm{~min}$ on ice. Cells were then washed gently with serumcontaining medium and incubated with secondary antibodies coupled to fluorescent dyes $\mathrm{Cy} 3$ or $\mathrm{Cy} 2$ for $20 \mathrm{~min}$ at room temperature in the dark. After washing with serum-free culture medium, cells were fixed with $4 \%$ formaldehyde for $15 \mathrm{~min}$ at room temperature, washed three times with PBS, stained with 4',6'-diamidino-2-phenylindole (DAPI) for 2 min, and finally washed three times with PBS, and then mounted with Fluoromount-G. Images were taken with an Olympus Fluoview 1000 microscope (Olympus).

Preparation, immunostaining, and cell migration of neural precursor cells. Mouse embryos (embryonic day 13.5) were decapitated and ganglionic eminences were collected, dissected, transferred to serum-free media, and mechanically dissociated by pipetting up and down with three fire-polished Pasteur pipettes with sequentially smaller diameters (Dihné et al., 2003). After dissociation, the neurospheres were centrifuged at $200 \times g$ for $1 \mathrm{~min}$ at room temperature, resuspended with $0.5 \mathrm{ml}$ of Accutase (Invitrogen), and incubated at $37^{\circ} \mathrm{C}$ for $10 \mathrm{~min}$. The $0.5 \mathrm{ml}$ of neural stem cell medium was added and pipetted up and down for 15-20 times. After centrifugation at $200 \times g$ for $5 \mathrm{~min}$ at room temperature, neurospheres were resuspended in neurosphere formation medium [DMEM/F12 (1:1) without L-glutamine, $1 \times$ B27 supplement, $0.02 \%$ sodium bicarbonate, $0.5 \mathrm{~m}$ HEPES, $16.6 \mathrm{~mm}$ glucose, $100 \mathrm{~mm}$ glutamine, 20 $\mathrm{ng} / \mathrm{ml}$ epidermal growth factor (EGF) and FGF-2] and maintained in culture for 4-5 d. For immunostaining, cultured neurospheres were allowed to settle for $10 \mathrm{~min}$, washed three times in precooled PBS, and fixed with $4 \%$ formaldehyde in filtered $0.4 \mathrm{M}$ cacodylate buffer, $\mathrm{pH} 7.3$, at $4^{\circ} \mathrm{C}$ for $1 \mathrm{~h}$ and dehydrated with $30 \%$ sucrose in cacodylate buffer at $4^{\circ} \mathrm{C}$ for $4 \mathrm{~h}$. The neurospheres were embedded in tissue-tag, frozen at $-30^{\circ} \mathrm{C}$, and sectioned at $14 \mu \mathrm{m}$ on a cryostat (Leica CM 3050; Leica Instruments). Sections were incubated with $10 \%$ goat serum and $0.1 \%$ Triton $\mathrm{X}-100$ at room temperature for $1 \mathrm{~h}$ and then with antibodies against PSA and histone $\mathrm{H} 1$ overnight at $4^{\circ} \mathrm{C}$. After washing three times with PBS, the sections were incubated with secondary antibodies coupled to the fluorescent dyes $\mathrm{Cy} 3$ or $\mathrm{Cy} 2$ for $1 \mathrm{~h}$ at room temperature in the dark, washed three times with PBS, incubated with bisbenzimide (Sigma-Aldrich) for staining of nuclei, and mounted with Fluoromount-G after additional washes in PBS. Images were taken with an Olympus Fluoview 1000 microscope. 
To determine the migration of neural stem cells from neurospheres (Decker et al., 2000), neurospheres were kept in culture for 10-15 d. Nonadherent neurospheres were seeded in $10 \mu \mathrm{l}$ droplets on glass coverslips coated with $0.02 \%$ PLL and laminin or histone $\mathrm{H} 1$ and maintained at $37^{\circ} \mathrm{C}$ for $20 \mathrm{~min}$. The medium was adjusted to $1 \mathrm{ml}$ per well with neurosphere formation medium without FGF-2 and EGF containing colominic acid and/or histone H1. After $24 \mathrm{~h}$, migration was assessed by measurement of the distance from the edge of the neurosphere to all cells having migrated out of the neurosphere using an Axiovert microscope and the AxioVision image analysis system 4.6 (Zeiss).

Analysis of femoral nerve regeneration and motor function. Femoral injury and analysis of regeneration were performed according to Simova et al. (2006). Analysis of femoral nerve regeneration and motor function was performed as described in detail previously (Mehanna et al., 2009), with the exception that the polyethylene tubes ( $3 \mathrm{~mm}$ length, $0.58 \mathrm{~mm}$ inner diameter; BD Biosciences) were filled either with PBS containing scaffold peptide that forms a gel matrix support ( $0.5 \%$ PuraMatrix Peptide Hydrogel, 3D; BD Biosciences), or PBS/scaffold peptide supplemented with histone $\mathrm{H} 1(100 \mu \mathrm{g} / \mathrm{ml})$. Retrograde labeling and evaluation of motoneuron number and soma size and analysis of degree of remyelination was performed as described in detail by Mehanna et al. (2009). The degree of myelination was estimated by calculating the $g$ ratio (axon-to-fiber diameter). Therefore, ultrathin sections of nerves were staining with toluidine blue after fixation, and the mean orthogonal diameters of the axon (inside the myelin sheath) and of the nerve fiber (including the myelin sheath) were measured.

\section{Results \\ Identification of an anti-idiotypic scFv antibody mimicking polysialic acid}

To identify novel PSA binding partners we used a PSAmimicking anti-idiotypic scFv antibody for immunoaffinity chromatography with detergent-solubilized fractions of mouse brain tissue. First, we isolated scFv antibodies that bind to a PSA antibody by screening a phage scFv library for binding to the immobilized PSA antibody. After four rounds of selection, 10 clones were isolated. Four of these clones contained the sequence LNDGPVTSA; five clones, the sequence GLPIDS; and one clone, the sequence SPFES in the CDR3 region of the $V_{H}$ region of the scFv antibody. All clones consisted of a $V_{H}$ and $V_{L}$ chain deriving from the VH1 (DP-3) and VL1 (1-d) antibody gene family.

Next, we checked by ELISA and surface plasmon resonance whether binding of the anti-idiotypic scFv antibodies to the PSA antibody mimicked binding of PSA. Since the yield of scFv antibody from the clone with the sequence SPFES in the CDR3 region was extremely low, this clone was not used further. As analyzed by ELISA, binding of the scFv antibody with the sequence GLPIDS to substrate-coated PSA antibody was inhibited in a concentration-dependent manner by the bacterial homolog of PSA, colominic acid. The fact that competition for binding with colominic acid is not complete may be attributed to nonspecific binding of the scFv antibody of the antibody. Other negatively charged polymers such as chondroitin sulfate $\mathrm{A}$, chondroitin sulfate $\mathrm{C}$, or heparin showed no inhibition of the binding (Fig. 1A). In addition, the scFv antibody did not bind to the HNK-1 antibody, which was used as a negative control antibody (data not shown). As assayed by surface plasmon resonance, the scFv antibody with the sequence GLPIDS bound in a concentration-dependent manner to the immobilized PSA antibody (Fig. $1 B$ ). This binding was also inhibited in a concentration-dependent manner by colominic acid (Fig. 1C). The $\mathrm{scFv}$ antibody with the sequence LNDGPVTSA showed identical results in ELISA and surface plasmon resonance (data not shown). These results verify that the scFv antibodies with the sequence GLPIDS and LNDGPVTSA,
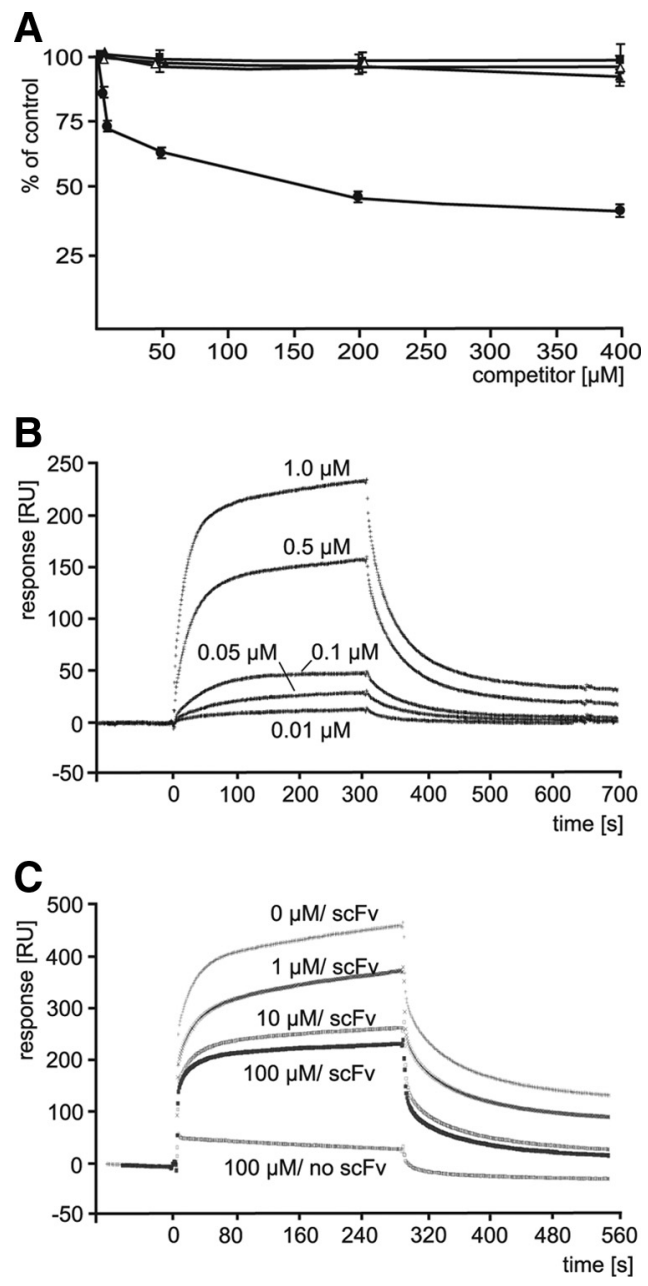

Figure 1. Anti-idiotypic scFv antibodies directed against a PSA antibody mimic PSA. A, Substrate-coated PSA antibody was preincubated with different concentrations of colominic acid (closed circles), chondroitin sulfate $A$ (closed triangles), chondroitin sulfate $C$ (open triangles), or heparin (closed rectangles) and incubated with purified scFv antibody with the sequence GLPIDS. Binding of the scFv antibody to the PSA antibody was determined by ELISA and binding in the presence of competitor was related to the binding in the absence of competitor, which was set to $100 \%$. Mean values \pm SD from three independent experiments are shown. $\boldsymbol{B}, \boldsymbol{C}$, Surface plasmon resonance experiments were performed using immobilized PSA antibody and different concentrations $(0.01,0.05,0.1$, 0.5 , and $1 \mu \mathrm{M}$ ) of scFv antibody with the sequence GLPIDS for injection $(\boldsymbol{B})$ or with a constant amount of scFv antibody $(5 \mu \mathrm{M})$ and different concentrations of colominic acid $(0,1,10$, and $100 \mu \mathrm{M})$ for injection or without scFv and $100 \mu \mathrm{m}$ colominic acid (100 $\mu \mathrm{m} / \mathrm{no}$ $\mathrm{scFv})(\mathbf{C})$. Binding of scFv was monitored by measuring the response signal in arbitrary units (RU). A representative experiment is shown.

which share the consensus motif $\mathrm{P}[\mathrm{VI}][\mathrm{TD}] \mathrm{S}$, are PSA-mimicking $\mathrm{scFv}$ antibodies.

To identify PSA binding partners, ELISA was performed using soluble purified $\mathrm{scFv}$ antibodies and different subfractions from mouse brain as substrate coats. No significant binding of $\mathrm{scFv}$ antibodies was observed (data not shown), possibly because of a low affinity of the scFv antibodies. We therefore increased the avidity and thus the functional affinity of the scFv antibodies. Since truncation of the linker region between the $\mathrm{V}_{\mathrm{H}}$ and $\mathrm{V}_{\mathrm{L}}$ domains of the scFv antibody results in enhanced dimerization and/or oligomerization of scFv monomers and thus in an increased avidity (Holliger et al., 1993), we truncated the linker region (Fig. 2A). FPLC analysis of the scFv antibodies without and with linker truncation showed that the nontruncated $\mathrm{scFv}$ 
A

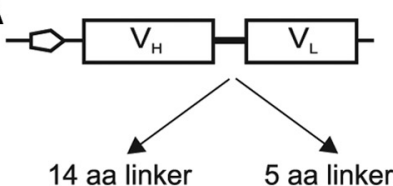

$\infty$

scFv monomer

C

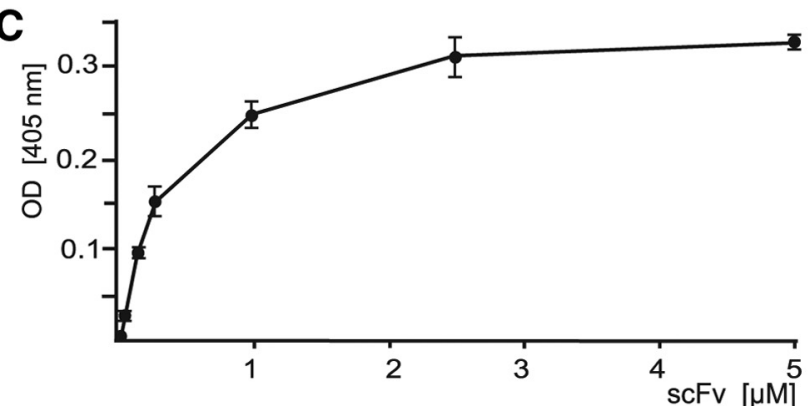

D

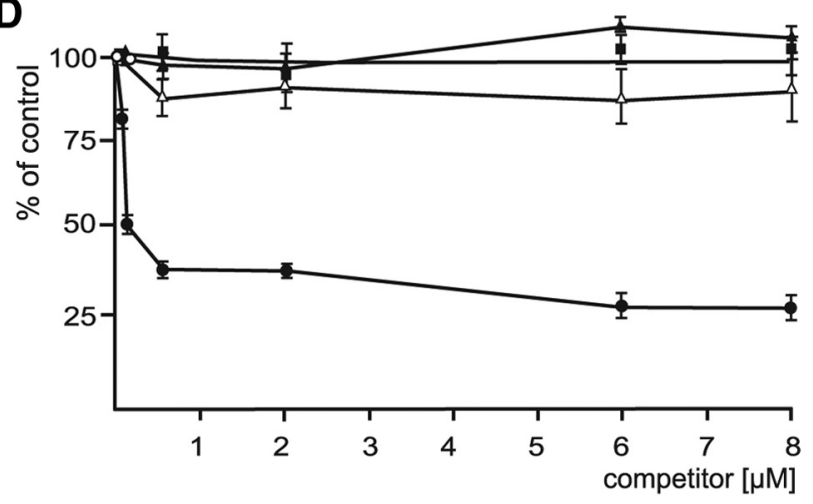

E

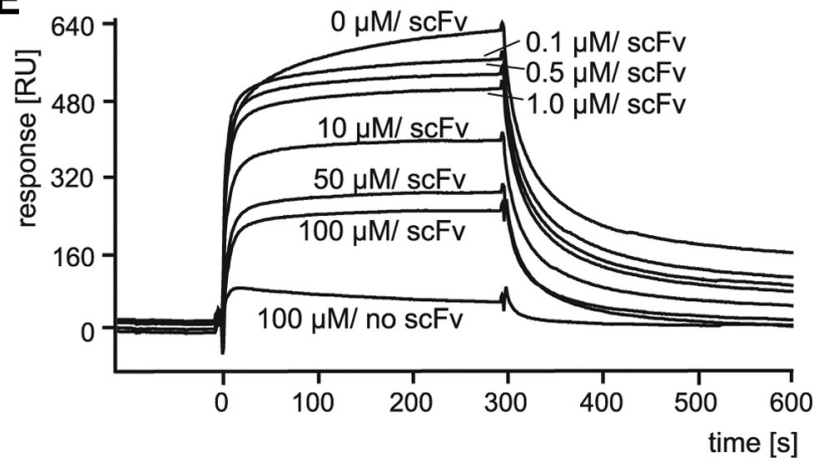

Figure 2. Affinity of PSA-mimicking scFv antibodies to a PSA antibody after linker truncation. $A$, The scFv antibody contains a linker of 14 aa ( 14 aa linker) between the $V_{H}$ and $V_{L}$ chains before truncation and 5 aa (5 aa linker) after truncation, which should result in increased formation of scFv antibody dimers. B, Purified scFv antibody with nontruncated (dashed line) or with truncated linker region (solid line) were separated by FPLC. The retention times of the monomeric and dimeric forms are indicated. $C$, Increasing concentrations of $s c F v$ antibody with truncated linker region were used in ELISA with substrate-coated PSA antibody. D, In the competition ELISA, different concentrations of colominic acid (closed circles), chondroitin sulfate A (closed triangles), chondroitin sulfate C (open triangles), or heparin (closed rectangles) and a constant amount of scFv antibody with truncated linker region were incubated with substratecoated PSA antibody. $\boldsymbol{C}, \boldsymbol{D}$, Mean values \pm SD from three independent experiments are shown for the binding of scFv antibody to the PSA antibody relative to the binding in the absence of competitor, which was set to $100 \%$. $\boldsymbol{E}$, Surface plasmon resonance experiments were performed using immobilized PSA antibody and different concentrations of colominic acid (0, 0.1, antibody with the sequence GLPIDS existed predominantly as a monomer with low amounts of dimer, whereas the truncated $s c F v$ antibody existed only as a dimer (Fig. $2 B$ ). After linker truncation, the scFv with the sequence LNDGPVTSA also existed only as a dimer (data not shown). The scFv antibodies with truncated linkers were analyzed by ELISA and surface plasmon resonance for binding to substrate-coated PSA antibody. By ELISA, the linker truncated $\mathrm{scFv}$ antibody with the sequence GLPIDS showed a concentration-dependent and saturable binding (Fig. $2 C)$. This binding was inhibited by colominic acid in a concentration-dependent manner, whereas heparin, chondroitin sulfate $\mathrm{A}$, or chondroitin sulfate $\mathrm{C}$ did not inhibit (Fig. 2D). By surface plasmon resonance, binding of the linker truncated scFv antibody with the sequence GLPIDS to immobilized PSA antibody was inhibited by colominic acid in a concentrationdependent manner (Fig. 2E). The linker truncated scFv antibody with the sequence LNDGPVTSA showed identical results in ELISA and surface plasmon resonance (data not shown). Interpretation of sensorgrams by a classical 1:1 binding model did not lead to convincing results reflecting the intrinsic property of $\mathrm{scFv}$ to exist as a mixture of monomer and dimer. However, a plot of equilibrium response versus concentration allowed us to estimate a range for the apparent affinity of the $\mathrm{scFv}(0.5-5 \mu \mathrm{M})$ that is well in accordance with published data on the binding of colominic acid to the PSA antibody (Evans et al., 1995). The linker truncated $\mathrm{scFv}$ antibodies were then applied to substrate-coated brain subfractions. The linker truncated $\mathrm{scFv}$ antibody with the sequence GLPIDS strongly bound to soluble proteins and detergent-solubilized membrane proteins from brains of early postnatal and adult mice, whereas the linker truncated $\mathrm{scFv}$ antibody with the sequence LNDGPVTSA showed only weak binding to soluble brain proteins and no binding to membrane proteins (Fig. 3A).

Identification of histone $\mathrm{H} 1$ as synaptic membrane-associated PSA binding partner using a PSA-mimicking scFv antibody The purified $\mathrm{scFv}$ antibody with the truncated linker and the sequence GLPIDS reacting with brain proteins was taken for affinity chromatography using different brain subfractions. By silver staining, a protein of $\sim 30 \mathrm{kDa}$ was detected in an eluate deriving from a subfraction enriched in membrane-associated proteins that were released from the membranes by alkaline treatment (Fig. 3B). The $\sim 30 \mathrm{kDa}$ band was analyzed by electrospray ionization-tandem mass spectrometry (MS/MS). After tryptic digestion of the band, two of the detected peptides could be assigned to histone H1. The MS/MS spectrum of a 1228.6936 $\mathrm{Da}$ and a $923.4724 \mathrm{Da}$ precursor mass (detected as doubly charged ion at $\mathrm{m} / z=614.8$ and 554.2) matched the tryptic peptide TSGPPVSELITK and ALAAAGYDVEK of mouse histone $\mathrm{H} 1$, respectively. The result of the chromatography suggested that membrane-associated histone $\mathrm{H} 1$ binds to PSA.

To verify the direct interaction between histone $\mathrm{H} 1$ and PSA, an ELISA was performed with purified colominic acid using purified histone $\mathrm{H} 1$ from calf thymus as substrate and GAPDH as a negative control substrate. In parallel, we also analyzed whether other histones, namely $\mathrm{H} 2 \mathrm{~A}, \mathrm{H} 2 \mathrm{~B}, \mathrm{H} 3$, or $\mathrm{H} 4$, bound to PSA. PSA

$\leftarrow$

$0.5,1.0,10,50$, and $100 \mu \mathrm{M})$ together with a constant amount of scFv antibody $(5 \mu \mathrm{M})$ with truncated linker region or without scFv and $100 \mu \mathrm{m}$ colominic acid (100 $\mu \mathrm{m} / \mathrm{no}$ scFv) for injection. Binding of scFv antibody in a representative experiment is shown. $\boldsymbol{B}-\boldsymbol{E}$, Results obtained for the scFv antibody with the sequence GLPIDS are shown. 

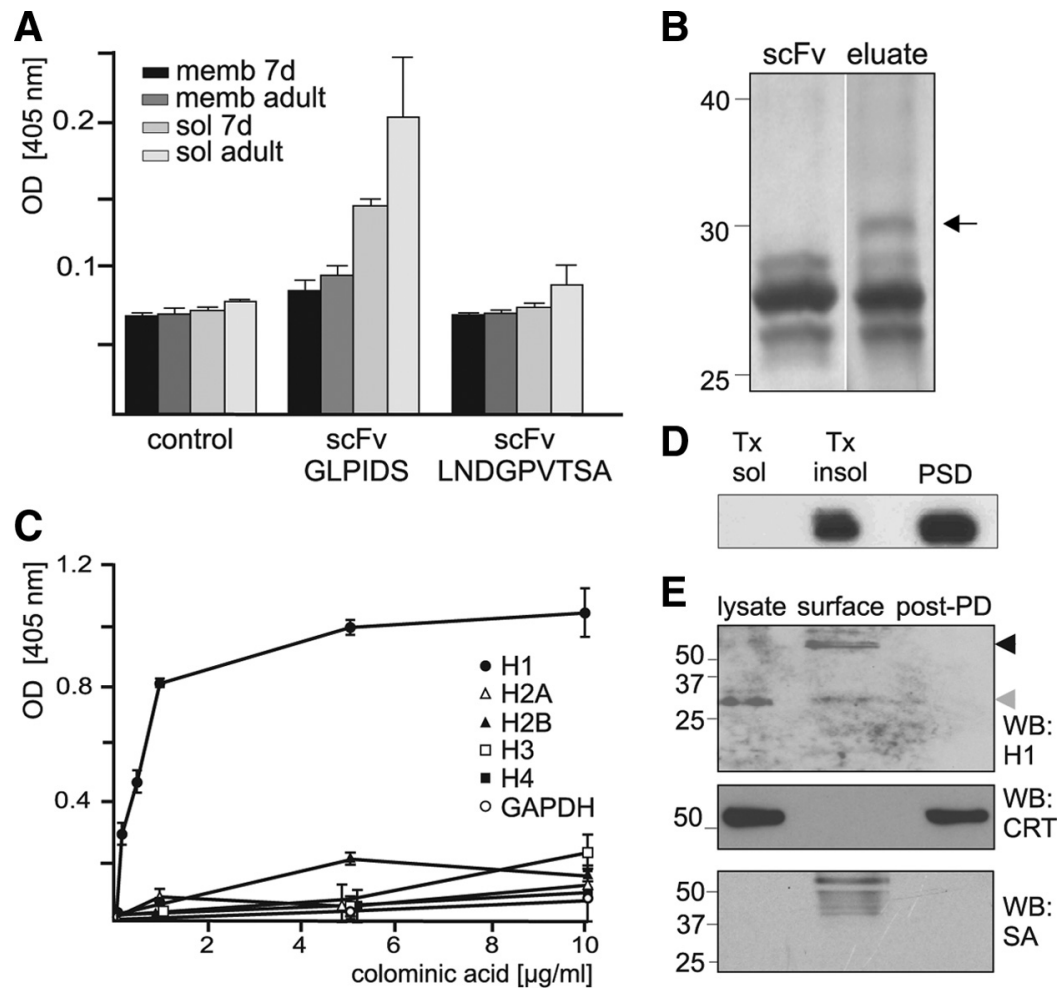

Figure 3. Identification of histone $\mathrm{H} 1$ as extracellular membrane-attached PSA binding partner using a PSA-mimicking scFv antibody for affinity chromatography. $\boldsymbol{A}$, Detergent-solubilized membrane (memb) or soluble (sol) brain proteins isolated from 7-d-old (7 d) or 2-month-old (adult) mice were used as substrate coat and incubated without (control) or with either scFv antibody with the sequence GLPIDS or LNDGPVTSA and truncated linker region. Mean values \pm SD from three independent experiments are shown for the binding of the scFv antibodies to soluble or membrane proteins. $\boldsymbol{B}$, Purified scFv antibody with the sequence GLPIDS was immobilized and used for affinity chromatography with membraneattached brain proteins obtained by alkaline treatment of membranes. Proteins binding to the scFv antibody were eluted and subjected to silver staining together with purified scFv antibody as a control. The position of the $30 \mathrm{kDa}$ protein band that was analyzed by mass spectrometry and identified as histone $\mathrm{H} 1$ is indicated by an arrow. C, Histone H1, H2A, H2B, H3, and $\mathrm{H} 4$ as well as GAPDH as negative control were substrate-coated and incubated with increasing concentrations of colominic acid. The binding of colominic acid was detected by ELISA using PSA antibody and corresponding HRP-conjugated secondary antibodies. Mean values \pm SD from three independent experiments performed in triplicate are shown. $\boldsymbol{D}$, Triton X-100-soluble (Tx sol), Triton X-100-insoluble membrane proteins (Tx insol), and PSDs were subjected to Western blot analysis using histone $\mathrm{H1}$-specific polyclonal rabbit antibody. $\boldsymbol{E}$, Cultured live cerebellar neurons were incubated with biotinylation reagent. Biotinylated surface proteins (surface) were precipitated by streptavidin beads and subjected to Western blot analysis using a monoclonal histone $\mathrm{H} 1$ antibody, a calreticulin antibody, or HRP-conjugated streptavidin (SA). Total cell lysate (lysate) and post-pull-down supernatant (post-PD) were used as controls. The biotinylated histone H1 form with apparent molecular weights of $\sim 60 \mathrm{kDa}$ (black arrowhead) and $\sim 30 \mathrm{kDa}$ (gray arrowhead) are indicated.

mainly detectable as a protein with an apparent molecular weight of $\sim 60 \mathrm{kDa}$ in the eluate containing biotinylated proteins, whereas only minor amounts of a $\sim 30 \mathrm{kDa}$ protein were detectable in the eluate (Fig. 3E). Histone H1 was detectable only as a $\sim 30 \mathrm{kDa}$ protein in the cell lysate and in the post-pull-down supernatant containing nonbiotinylated proteins (Fig. 3E). Probing the Western blots with HRP-conjugated streptavidin showed biotinylated proteins only in the eluate (Fig. 3E) demonstrating that the cell surface biotinylation and the isolation of biotinylated proteins had been successful. The intracellular protein calreticulin was detectable by Western blot analysis in cell lysate and post-pulldown supernatant, but not in the eluate of biotinylated proteins (Fig. 3E), indicating the intactness of the cells during cell surface biotinylation and serving as a control. The results of the cell surface biotinylation thus indicate that histone $\mathrm{H} 1$ indeed is present at the cell surface as extracellular protein. In addition, because of the molecular weights of the cell surfacebiotinylated histone $\mathrm{H1}$, which is mainly $\sim 60 \mathrm{kDa}$, and the intracellular nonbiotinylated histone $\mathrm{H1}$, which is $\sim 30 \mathrm{kDa}$, we assume that extracellular histone H1 mainly exists as a dimer.

To further corroborate the notion that histone $\mathrm{H} 1$ interacts with PSA at the cell surface, we immunocytochemically colabeled histone $\mathrm{H} 1$ and PSA at the surface of cultured live cerebellar neurons and Schwann cells using a polyclonal histone $\mathrm{H} 1$ antibody and a monoclonal PSA antibody. Confocal microscopic analysis showed histone $\mathrm{H} 1$ and PSA immunoreactivity both at the surface of neuronal cell bodies and along neurites (Fig. $4 \mathrm{~A}$ ) as well as processes of Schwann cells (Fig. $4 B$ ). The superimposed images revealed a sig-

directly interacted with histone $\mathrm{H} 1$ in a concentration-dependent and saturable manner, whereas it did not interact with GAPDH or with any of the other histones (Fig. 3C).

To confirm that histone $\mathrm{H} 1$ is tightly associated with the plasma membrane, the distribution of histone $\mathrm{H} 1$ in brain membrane subfractions was analyzed on detergent treatment. By Western blot analysis, a histone H1-specific antibody reacted with a $\sim 30 \mathrm{kDa}$ protein only in Triton X-100-insoluble postsynaptic densities or in the Triton X-100-insoluble, but not in the detergent-soluble fraction of the subfraction enriched in synaptic membranes (Fig. 3D), indicating that histone $\mathrm{H} 1$ is tightly associated with synaptic membranes in detergent-insoluble membrane microdomains such as PSDs.

Since PSA is exposed at the cell surface, we investigated whether histone $\mathrm{H} 1$ is present extracellularly. To test this, live cerebellar neurons in culture were cell surface biotinylated and biotinylated proteins were isolated by streptavidin beads. In Western blot analysis with a histone $\mathrm{H} 1$ antibody, histone $\mathrm{H} 1$ was nificant portion of histone $\mathrm{H} 1$ colocalizing with PSA (Fig. 4A,B).

\section{Histone $\mathrm{H} 1$ alters PSA-induced neurite outgrowth of cerebellar neurons}

Next, we investigated whether the interaction between PSA and histone $\mathrm{H} 1$ has functional consequences. First, we tested whether histone $\mathrm{H} 1$ influences neurite outgrowth. Cerebellar neurons were grown on substrate-coated PLL or PLL with histone $\mathrm{H} 1$ or as control with laminin or histone $\mathrm{H} 2 \mathrm{~A}, \mathrm{H} 2 \mathrm{~B}, \mathrm{H} 3$, and H4. In parallel, neurons were grown on PLL in the absence or presence of soluble histone $\mathrm{H} 1$ and/or soluble PSA or as control in the presence of histone $\mathrm{H} 2 \mathrm{~A}, \mathrm{H} 2 \mathrm{~B}, \mathrm{H} 3$, or $\mathrm{H} 4$. Neurite outgrowth on substrate-coated histone $\mathrm{H} 1$ was enhanced by approximately threefold when compared with PLL and nearly reached values obtained for the positive control substrate laminin (Fig. 5A,B). Similarly, neurite outgrowth on PLL was increased with soluble histone $\mathrm{H} 1$ and soluble PSA (Fig. 5A,C), indicating that soluble PSA and histone $\mathrm{H} 1$ both trigger neurite outgrowth. Moreover, a 
concentration-dependent promotion of neurite outgrowth by both substratecoated and soluble histone $\mathrm{H} 1$ was observed (Fig. 5C). However, in the concomitant presence of soluble histone $\mathrm{H} 1$ and PSA, neurite outgrowth was not increased and was similar to that observed in the absence of both histone $\mathrm{H} 1$ and PSA (Fig. $5 A, C$ ), indicating that soluble histone $\mathrm{H} 1$ and PSA had interacted and were no longer able to trigger neurite outgrowth. These results indicate that the interaction between histone $\mathrm{H} 1$ and PSA is involved in neurite outgrowth. Unexpectedly, substrate-coated and soluble histone $\mathrm{H} 2 \mathrm{~A}, \mathrm{H} 2 \mathrm{~B}$, and $\mathrm{H} 3$ also promoted neurite outgrowth (Fig. 5B,C), whereas $\mathrm{H} 4$ had no effect on neurite outgrowth as coated (Fig. 5B) or soluble (data not shown) substrate. To analyze whether neurite outgrowth induced by histone $\mathrm{H} 1$ or the other histones depends on PSA at the surface of cerebellar neurons, we measured neurite lengths of neurons treated with the PSA degrading endoglycosidase $\mathrm{N}$ or with the PSA-specific antibody. On the control substrates PLL or laminin, neurite outgrowth in the presence of PSA antibody or endoglycosidase $\mathrm{N}$ was not altered compared with that observed in the absence of antibody and enzyme (Fig. $5 D)$. In addition, the enhanced neurite outgrowth in the presence of soluble histone $\mathrm{H} 2 \mathrm{~A}, \mathrm{H} 2 \mathrm{~B}$, or $\mathrm{H} 3$ was also not inhibited either by the PSA-specific antibody or by the endoglycosidase $\mathrm{N}$ treatment (Fig. $5 D$ ), indicating an PSA-independent enhancement of neurite outgrowth by these histones. In contrast, the enhanced neurite outgrowth in the presence of soluble histone $\mathrm{H} 1$ was reduced nearly to that observed on PLL in the presence of either the PSA-specific antibody or the PSAdegrading enzyme (Fig. 5D). Thus, PSA at the surface of neurons mediates histone $\mathrm{H} 1$-induced neurite outgrowth.

To investigate whether endogenous extracellular histone $\mathrm{H} 1$ is involved in PSA-mediated neurite outgrowth, neurite outgrowth was determined in the absence or presence of soluble PSA and/or a polyclonal histone $\mathrm{H} 1$ antibody with the expectation that the antibody binds to endogenous histone $\mathrm{H} 1$ and blocks its effect on neurite outgrowth. Addition of soluble histone $\mathrm{H} 1$ antibody indeed blocked neurite outgrowth promotion by soluble PSA, whereas the antibody had no significant effect on neurite outgrowth in the absence of PSA (Fig. 5E). Surprisingly, laminininduced neurite outgrowth was also reduced in the presence of the histone $\mathrm{H} 1$ antibody independently of the presence of PSA (Fig. $5 E$ ). Since neurite outgrowth enhanced by laminin was not affected in the presence of the PSA-specific antibody or endoglycosidase $\mathrm{N}$ (Fig. 5C), it is likely that laminin stimulates neurite outgrowth in a histone H1-dependent, but PSAindependent manner.
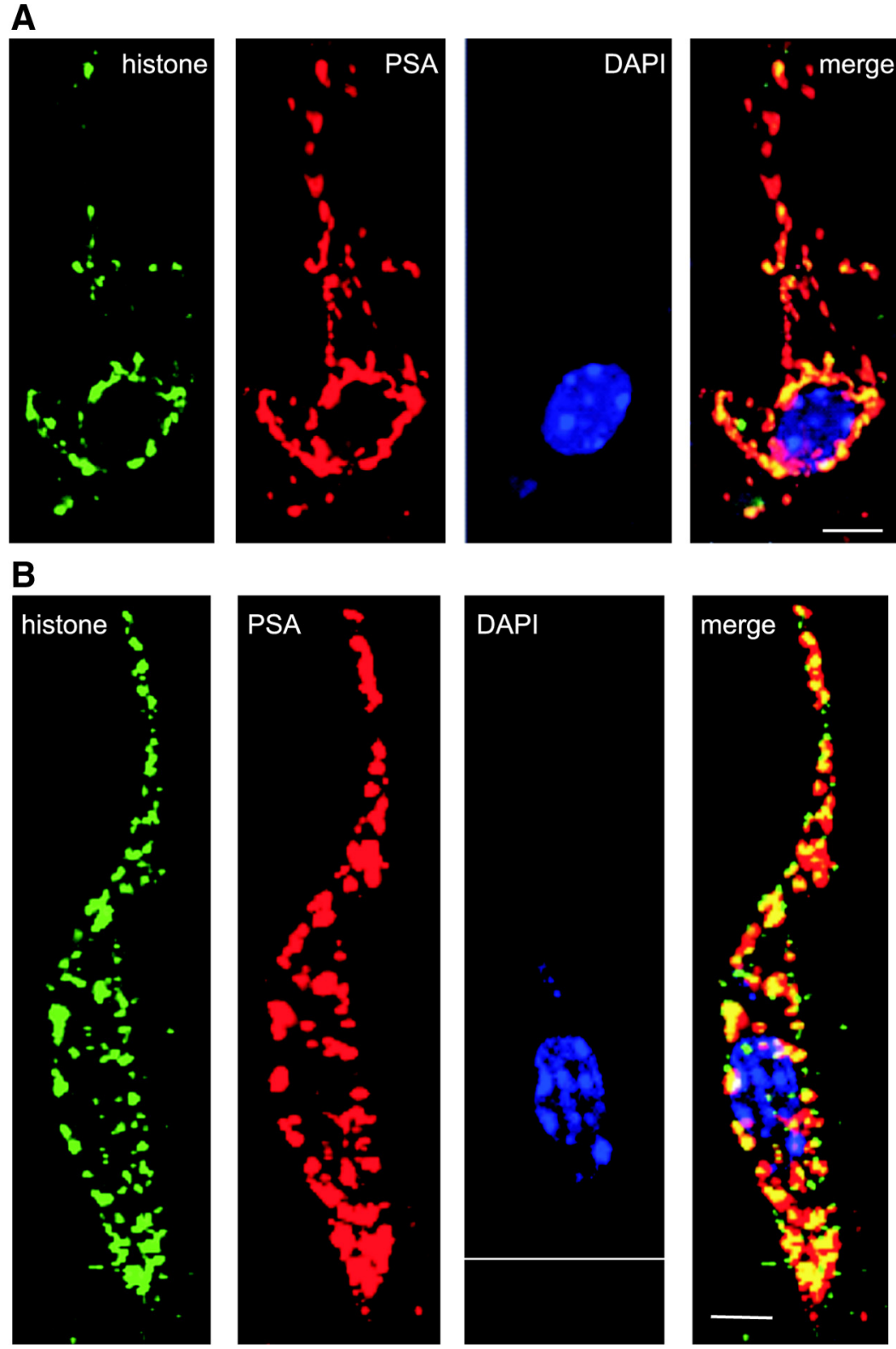

Figure 4. Colocalization of histone $\mathrm{H} 1$ and PSA at the surface of live cerebellar neurons and Schwann cells. A, Cultured live cerebellar neurons $(\boldsymbol{A})$ or Schwann cells $(\boldsymbol{B})$ were immunostained with rabbit polyclonal histone $\mathrm{H} 1$ antibody, mouse monoclonal nuclei were stained with DAPI. Superimpositions of histone $\mathrm{H} 1$ and PSA staining show partial colocalization (seen in yellow) at the surface of cell bodies and processes. Scale bars, $10 \mu \mathrm{m}$.

Histone $\mathrm{H} 1$ and PSA influence process formation and proliferation of Schwann cells

Since we showed that histone H1 and PSA colocalize at the Schwann cell surface and since a PSA-mimicking peptide and overexpression of PSA by Schwann cells improve myelination by Schwann cells in vivo (Papastefanaki et al., 2007; Mehanna et al., 2009), we tested the effects of histone $\mathrm{H} 1$ on Schwann cell process formation. Schwann cells isolated from dorsal root ganglia of early postnatal mice were cultured on substrate-coated PLL, laminin, histone $\mathrm{H} 1$, or PLL in the presence of soluble histone $\mathrm{H} 1$ protein and/or soluble PSA. Morphometric analysis of Schwann cell process length revealed an increase of process length on substrate-coated histone $\mathrm{H} 1$ relative to PLL substrate and also in the presence of soluble PSA or soluble histone $\mathrm{H} 1$ (Fig. $6 A, B$ ). The concomitant presence of soluble 


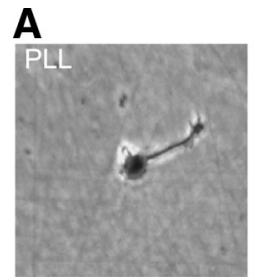

B

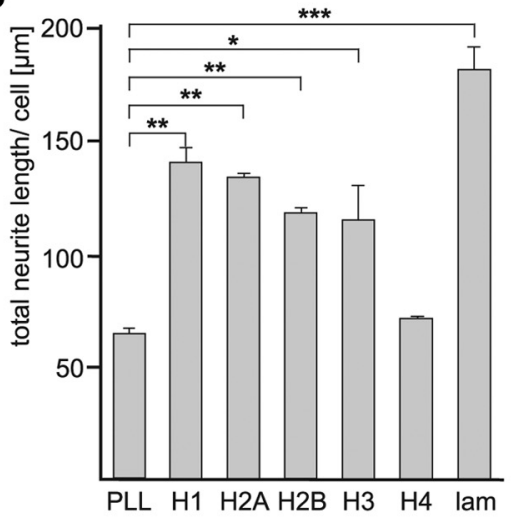

D
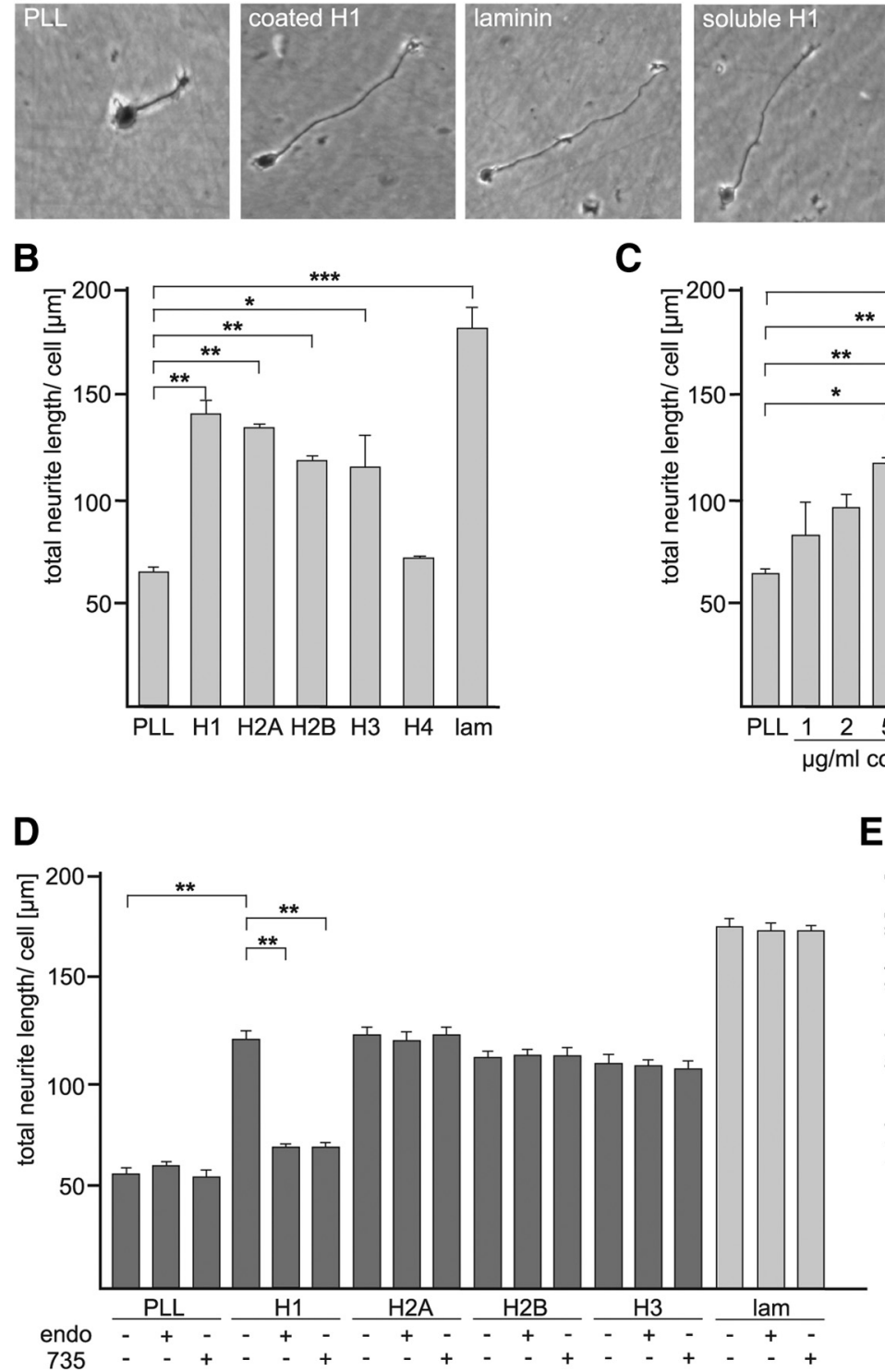

C

E
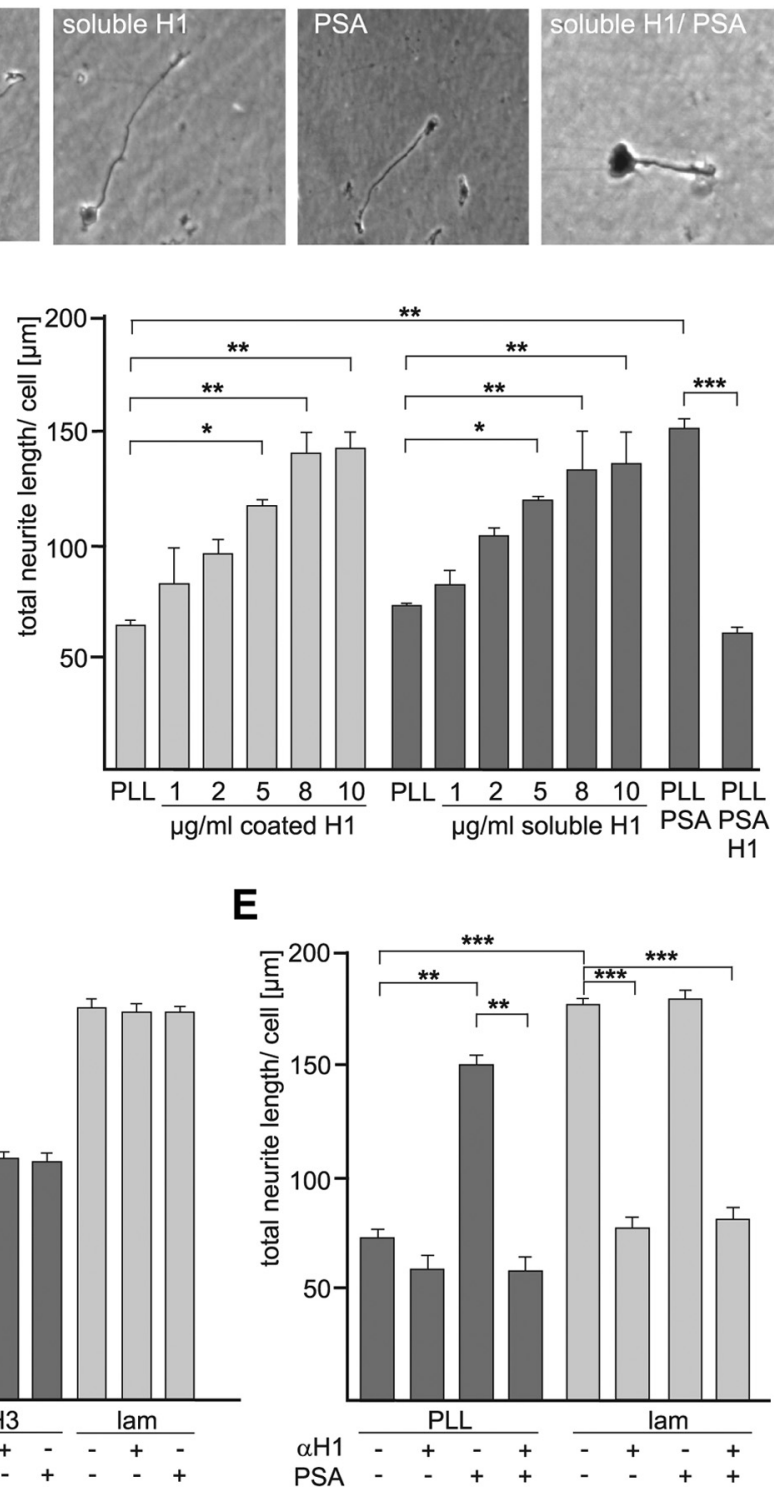

Figure 5. Histone H1 promotes neurite outgrowth of cerebellar neurons in a PSA-dependent manner. Primary cultures of cerebellar neurons were grown on substrate-coated PLL or PLL with $10 \mu \mathrm{g} / \mathrm{ml}$ histone H1, H2A, H2B, H3, or H4, or laminin (lam), on PLL with increasing amounts of histone H1 or on PLL in the presence of increasing amounts of soluble histone $\mathrm{H} 1$ or on PLL in the presence of $10 \mu \mathrm{g} / \mathrm{ml}$ soluble PSA and histone $\mathrm{H} 1(\boldsymbol{A}, \boldsymbol{C})$, on PLL or laminin in the absence and presence of PSA-specific antibody (735) or endoglycosidase $\mathrm{N}$ (endo) and/or histone $\mathrm{H} 1, \mathrm{H} 2 \mathrm{~A}, \mathrm{H} 2 \mathrm{~B}, \mathrm{H} 3$, or $\mathrm{H} 4(\boldsymbol{D})$, or on substrate-coated PLL or laminin in the absence or presence of soluble PSA and/or histone $\mathrm{H} 1$ antibody ( $\alpha \mathrm{H} 1)(\boldsymbol{E})$. $\boldsymbol{A}$, Images of representative neuron on substrate-coated PLL in the absence or presence of PSA and/or soluble histone $\mathrm{H1}$, on substrate-coated histone $\mathrm{H} 1$ or on control substrate laminin are shown. $\boldsymbol{B}-\boldsymbol{E}$, The total length of neurites per cerebellar neuron was determined. The asterisks, double asterisks, and triple asterisks denote $p<0.05, p<0.01$, and $p<0.001$ obtained by the two-tailed $t$ test, respectively, from $n=\sim 100$ neurons in three independent experiments.

PSA and histone H1 led to a neutralization of the promotion seen with PSA and histone $\mathrm{H} 1$ when applied individually (Fig. $6 A, B)$, indicating that the exogenously added histone $\mathrm{H} 1$ and PSA likely bound to each other and were no longer able to promote process extension.

We also investigated the effect of histone $\mathrm{H} 1$ and PSA on Schwann cell proliferation by analysis of BrdU incorporation and found that Schwann cell proliferation was enhanced by substratecoated histone $\mathrm{H} 1$ and in the presence of soluble histone $\mathrm{H} 1$ and soluble PSA, when compared with proliferation in the absence of PSA and histone H1, respectively (Fig. 6C). The mixture of soluble histone $\mathrm{H} 1$ and soluble PSA decreased the enhanced proliferation seen with histone $\mathrm{H} 1$ or PSA to levels observed on the PLL substrate (Fig. 6 C). These results show that PSA and histone $\mathrm{H} 1$ are involved in proliferation and process formation of Schwann cells.

\section{Histone $\mathrm{H} 1$ and PSA alter migration of neural progenitor cells}

Previous studies have suggested that PSA is required for migration of neural progenitor cells (Hu et al., 1996; Chazal et al., 2000; $\mathrm{Hu}, 2000$; Patrzykat et al., 2001; Angata et al., 2007). Based on these studies, we next investigated whether histone $\mathrm{H} 1$ affects neural progenitor cell migration. Beforehand, we investigated by immunostaining whether neural progenitor cells in neurospheres express histone $\mathrm{H} 1$ and PSA and observed that these cells not only express both histone $\mathrm{H} 1$ and PSA at their cell surface but also that both protein partially colocalize (Fig. 7A). For analysis of 
migration, the neurospheres were maintained on substrate-coated histone $\mathrm{H} 1$ and in the presence of soluble histone $\mathrm{H} 1$ or soluble PSA. The number of cells migrating from the neurospheres and the distance between migrating cells and the edge of the neurospheres were determined and used as criteria for migration. On PLL, the number of cells that had migrated out of the neurospheres was low (Fig. $7 B$ ). Migration of neural progenitor cells was enhanced when either soluble PSA or soluble histone $\mathrm{H} 1$ were applied, whereas a mixture of PSA and histone $\mathrm{H} 1$ only slightly affected migration (Fig. $7 B$ ). Compared with the positive control substrate laminin, substrate-coated histone $\mathrm{H} 1$ enhanced migration almost equally well (Fig. 7B). These findings suggest that both histone $\mathrm{H} 1$ and PSA are important for neural progenitor cell migration in vitro.

\section{Histone $\mathrm{H} 1$ promotes functional recovery after femoral nerve injury in adult mice}

Since PSA enhances regeneration after injury of the peripheral nervous system of adult mice (Mehanna et al., 2009) and since we have observed that histone $\mathrm{H} 1$ has beneficial effects on Schwann cells and neurons in vitro, we addressed the question whether histone $\mathrm{H} 1$ enhances regeneration after femoral nerve injury. The function of the quadriceps muscle was evaluated during a 4 month period after injury after application of histone $\mathrm{H} 1$ or PBS. Femoral nerve injury in mice induces changes in gait that can be quantitatively evaluated, for instance by the foot-base angle (FBA) (Fig. $8 A-D, I)$ and the heels-tail angle (HTA) (Fig. $8 E-H, J$ ) during beam walking (Fig. $8 A, H$ ). Changes in gait are caused by impaired extensor function of the quadriceps muscle leading to abnormal external rotation of the ankle and high heel position at defined gait cycle phases. We used these parameters to evaluate the effect of histone $\mathrm{H} 1$ on locomotor recovery. One week after injury, the degree of functional impairment, as evaluated by the increase of the foot-base angle (Fig. $8 \mathrm{~B}$ ) and decrease of the heels-tail angle (Fig. $8 F$ ) compared with the preoperative values (Fig. $8 A, E$ ) was found to be similar between groups of mice treated with histone $\mathrm{H} 1$ and PBS. When compared with the PBS control groups (Fig. $8 C, G, I, J)$, better functional improvement was observed in histone H1-treated mice at 2 (Fig. $8 I, J$ ), 3 (Fig. 8I,J), and 4 (Fig. $8 D, H-J)$ months after injury. Analysis of the protraction length ratio, which is another parameter for assessment of functional recovery measuring the ability of a mouse to extend the hindlimb to catch an object with its hindpaws, was not different between the two groups. However, there was a tendency for better recovery of hindlimb extension after application of histone $\mathrm{H} 1 \mathrm{com}$ pared with PBS (Fig. $8 \mathrm{~K}$ ). Superior functional recovery after histone $\mathrm{H} 1$ treatment was apparent when the stance recovery index was calculated for both angles on an individual animal basis
(Fig. $8 L$ ). Stance recovery index is a measure of the individual degree of recovery and reflects the degree of postoperative normalization of the quadriceps extensor function during ground locomotion. The recovery index of animals treated with histone $\mathrm{H} 1$ reached values at 3 and 4 months that were remarkably the same as the preoperative values, which are set to $100 \%$, indicating complete functional recovery. At the same time, recovery in the control group after 3 and 4 months was only 62 and 76\%, respectively. Thus, application of histone $\mathrm{H} 1$ treatment leads to a most superior functional outcome in peripheral nerve regeneration.

Histone $\mathrm{H} 1$ promotes survival, extent, and precision of axonal regrowth, and reinnervation of motoneurons

To search for structural correlates of the superior functional recovery after application of histone $\mathrm{H} 1$, retrograde labeling of regenerated motoneurons was performed in animals after analyzing functional recovery. The number of motoneurons backlabeled through the motor (quadriceps) nerve branch that represent correctly projected regrown motoneurons was remarkably increased in animals to which histone $\mathrm{H} 1$ had been 

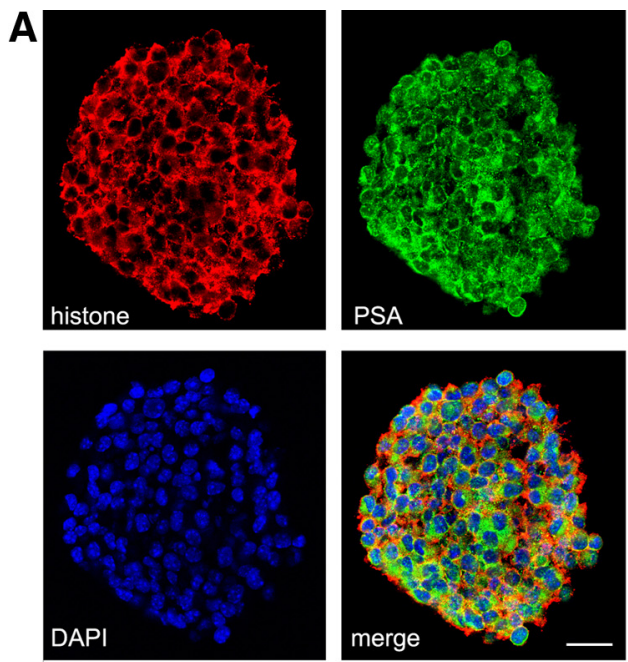

B
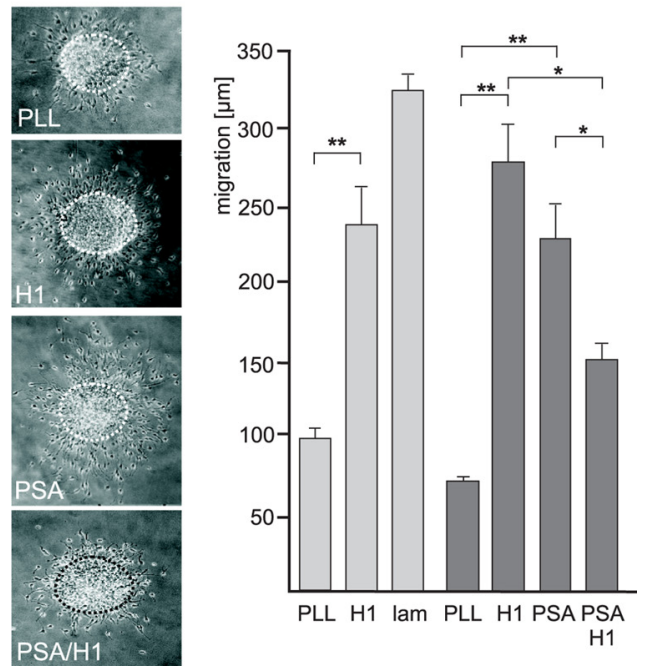

$\mathrm{H} 1$

Figure 7. Histone $\mathrm{H} 1$ and PSA are expressed by neurospheres and affect migration of neural progenitor cells. $A$, Slices of neurospheres were stained with histone H1- and PSA-specific antibodies followed by DAPI staining. Superimpositions of histone $\mathrm{H} 1$ and PSA staining show partial colocalization (seen in yellow) at the surface of neural precursor cells. Scale bar, $10 \mu \mathrm{m}$. B, Neurospheres were seeded onto substrate-coated PLL (PLL), histone $\mathrm{H} 1$ (H1), or laminin (lam) or on substrate-coated PLL in the presence of soluble PSA and/or histone H1. Micrographs displaying neurospheres (borders are indicated by dashed lines) with cells migrating out of the neurospheres in the absence (PLL) or presence of soluble PSA (PSA), soluble histone H1 (H1), or both soluble PSA and soluble histone H1 (PSA/H1) (left panel) and the quantification of the total distance reached by all migrating cells measured from the border of the neurosphere (right panel) are shown. Mean values \pm SD from three independent experiments are shown. The asterisks and double asterisks denote $p<0.05$ and $p<0.01$, respectively, obtained by the two-tailed $t$ test from 20 neurospheres per group from three independent experiments.

applied relative to PBS-treated animals (Fig. 9A). The number of backlabeled motoneurons from the sensory (saphenous) branch representing incorrectly projecting neurons was considerably decreased in animals treated with histone $\mathrm{H} 1 \mathrm{com}-$ pared with PBS-treated animals (Fig. 9A). The small numbers of motoneurons backlabeled through both femoral nerve branches were similar in histone H1- or PBS-treated mice (Fig. 9A). Although not reaching the level of statistical significance, a noticeable increase in the total number of labeled neurons was observed in histone $\mathrm{H1}$-treated mice relative to PBS-treated mice (Fig. 9A). Since numbers of retrogradely labeled motoneurons reflect the extent of motoneuron survival (de la Cruz et al., 1994; Waters et al., 1998; Asahara et al., 1999, Guseva et al., 2009), we conclude that treatment with histone $\mathrm{H} 1$ reduces motoneuron death, a characteristic feature of the femoral nerve injury paradigm in mice (Simova et al., 2006). In addition, histone H1 application increased the number of regenerated motoneurons projecting to the appropriate motor nerve branch and thus increased preferential motor reinnervation, which is a characteristic feature of femoral nerve regeneration (Brushart, 1988; Al-Majed et al., 2000; Franz et al., 2005; Vrbova et al., 2009). In conclusion, our results show that better functional recovery in histone $\mathrm{H} 1$-treated mice is attributable to better motoneuron regeneration, since extent and precision of motor reinnervation was improved compared with control mice.

Since a significant correlation between recovery index and motoneuron size was found 3 months after femoral nerve injury (Simova et al., 2006; Ahlborn et al., 2007), we measured soma size of motoneurons regrowing their axons correctly and found a significant increase in soma size of these motoneurons in histone H1- versus PBS-treated animals. No difference in soma size of incorrectly projecting motoneurons was observed among the groups (Fig. 9B). Thus, better functional recovery of histone $\mathrm{H1}$ treated mice can be attributed to larger motoneuron size, which is an indicator of a better functional state of regenerated motoneurons (Simova et al., 2006; Ahlborn et al., 2007).

We also analyzed regenerated nerves with regard to the degree of remyelination as evaluated by the $g$ ratio (axon- to fiberdiameter ratio). The frequency distributions of the $g$ ratio for axons of histone H1- or PBS-treated injured nerves were similar and shifted to higher values when compared with values for intact axons (Fig. 9C), indicating that histone $\mathrm{H} 1$ does not enhance remyelination or myelin thickness of injured nerves compared with those that were treated with PBS only.

\section{Discussion}

In the present study, we isolated PSA-mimicking anti-idiotypic scFv antibodies by screening a scFv phage library with a PSA antibody and identified histone $\mathrm{H} 1$ as a novel interaction partner of PSA using the PSA-mimicking scFv antibody with the sequence GLPIDS in the CDR3 region of its $\mathrm{V}_{\mathrm{H}}$ chain for immunoaffinity chromatography of membrane-associated brain proteins.

ELISA experiments showed that histone $\mathrm{H} 1$ directly interacts with PSA, whereas other histones, namely histone $\mathrm{H} 2 \mathrm{~A}, \mathrm{H} 2 \mathrm{~B}, \mathrm{H} 3$, and $\mathrm{H} 4$, do not bind to PSA. This uniqueness of histone $\mathrm{H} 1$ to interact with PSA is further underscored by neurite outgrowth experiments showing that only histone $\mathrm{H} 1$ promotes neurite outgrowth in a PSA-dependent manner, whereas neurite outgrowth induced by the other histones or by laminin is PSA-independent. Interestingly, laminin-induced neurite outgrowth appears to depend on histone $\mathrm{H} 1$ since histone $\mathrm{H} 1$ antibody inhibits the laminin-induced neurite outgrowth. However, data from ELISA (data not shown) indicated that laminin does not directly bind to histone $\mathrm{H} 1$. The mechanism by which histone $\mathrm{H} 1$ and the other histones trigger PSA-dependent or PSA-independent neuronal responses such as neurite outgrowth are not yet known and will require additional investigations.

Immunostaining of live cerebellar neurons, Schwann cells, and neural progenitor cells indicated that extracellular histone $\mathrm{H} 1$ and PSA colocalize. Cell surface biotinylation of cerebellar neurons confirmed the extracellular localization of histone $\mathrm{H} 1$. Furthermore, the results of the in vitro functional tests (e.g., neurite outgrowth from cerebellar neurons, Schwann cell process formation and proliferation, as well as migration of neural progenitor cells) indicated that extracellular histone $\mathrm{H} 1$ interacts 
with PSA at the cell surface and that this interaction induces the observed effects of histone $\mathrm{H} 1$ on the investigated neural cells. Indications for the unusual extracellular location of histone $\mathrm{H} 1$, which was first identified as a nuclear protein, have been found in several other studies: histone $\mathrm{H} 1$ has been observed at the cell surface of cultured mouse cortical neurons (Bolton and Perry, 1997), human monocytes (Holers and Kotzin, 1985), activated human peripheral blood lymphocytes (Watson et al., 1995), cultured T-cells (Watson et al., 1995, 1999), a macrophage cell line (Brix et al.,1998), and skeletal muscle cells (Henriquez et al., 2002). So far, the mechanism(s) by which histone $\mathrm{H} 1$ crosses the membrane are not known. Since penetration of extracellular histones through the plasma membrane into the cell has been demonstrated (Hariton-Gazal et al., 2003), it is conceivable that a similar mechanism may exist for the export of histone $\mathrm{H} 1$.

Extracellular histone $\mathrm{H} 1$ has been shown to bind to cell surface heparan sulfate proteoglycans (Watson et al., 1999) and lipopolysaccharide (Hampton et al., 1988; Bolton and Perry, 1997) and apparently binds to amyloid precursor protein (Potempska et al., 1993) and associates with $\beta$-amyloid in amyloid plaques (Duce et al., 2006). We identified PSA as another novel binding partner of extracellular histone $\mathrm{H} 1$ and showed that the effects of histone $\mathrm{H} 1$ on neural cells, such as neurite outgrowth, are mediated by PSA. For instance, application of the PSA antibody or enzymatic degradation of PSA abolished the enhanced neurite outgrowth from cerebellar neurons. It is worthwhile to mention that, like histone H1, PSA also binds to heparan sulfate proteoglycans (Storms and Rutishauser 1998) and that the heparan sulfate-dependent interaction between heparan sulfate proteoglycans, in particular perlecan, and extracellular histone $\mathrm{H} 1$ plays an important role in skeletal muscle development and regeneration (Henriquez et al., 2002).

In our study, in vivo experiments showed that histone $\mathrm{H} 1$ improves regeneration of injured femoral nerve of mice. Administration of histone $\mathrm{H} 1$ to lesioned femoral nerves promotes survival of motoneurons, axonal regrowth, precision of reinnervation, and better regeneration of the injured femoral nerve, leading to a remarkable complete functional recovery of locomotion after injury. We have observed similar positive effects on recovery after femoral nerve lesion in mice for PSA using PSA-mimicking peptides (Mehanna et al., 2009). The time course of improvement is similar for histone $\mathrm{H} 1$ and PSA-mimicking peptides with positive effects becoming apparent later (i.e., at 2-3 months after injury and treatment). Since the local availability of a protein is most likely limited to hours or at
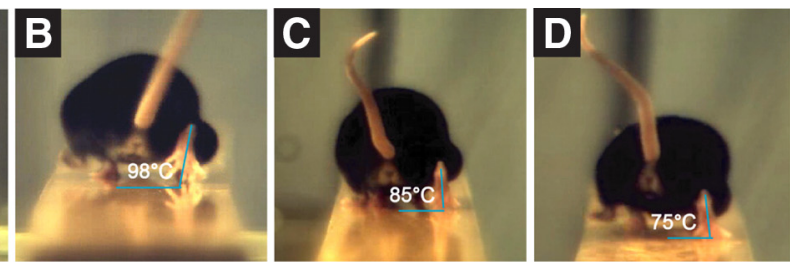
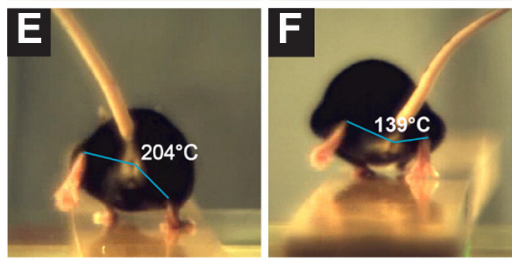

1 week after injury histone $\mathrm{H}^{1}$
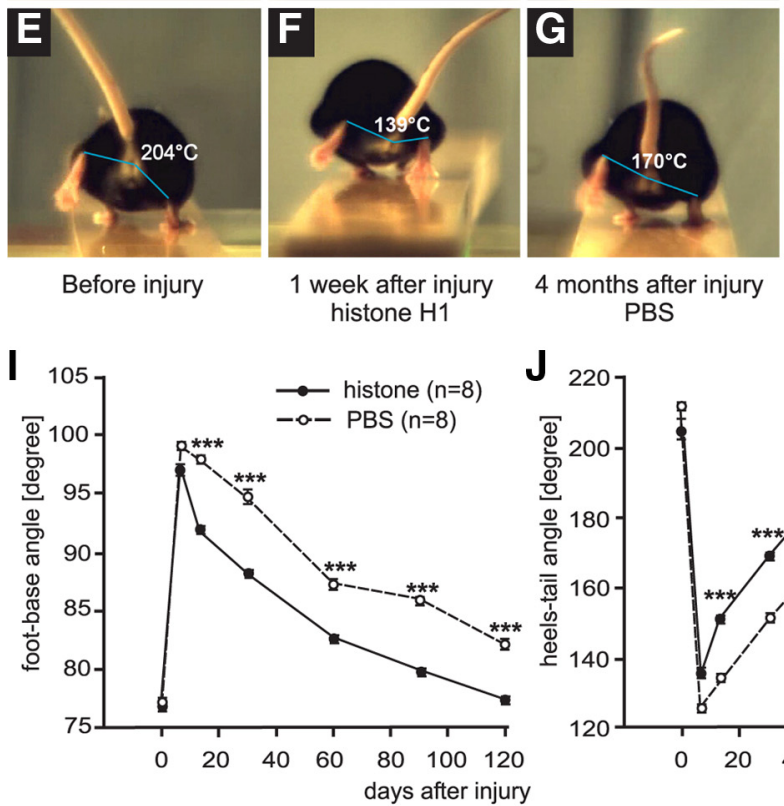

4 months after injury PBS
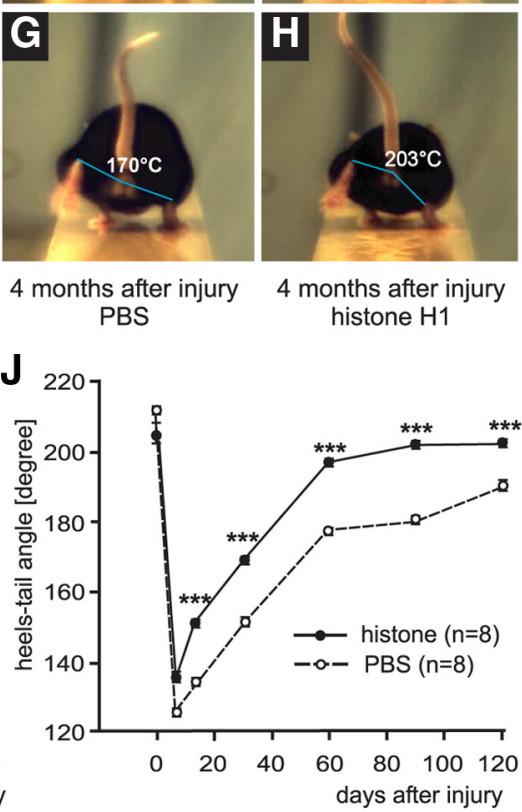

4 months after injury histone $\mathrm{H} 1$
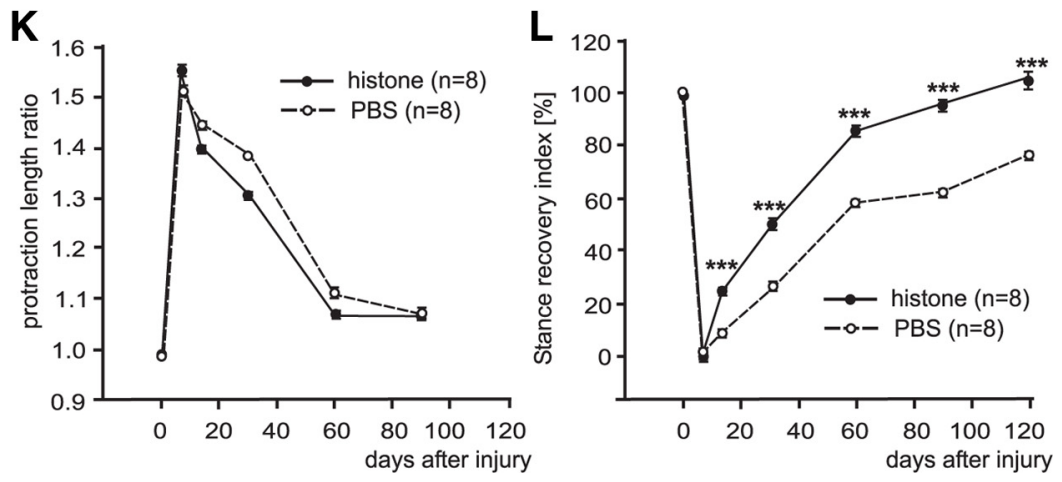

Figure 8. Analysis of motor function after femoral nerve injury and application of histone H1. FBA $(\boldsymbol{A}-\boldsymbol{D})$ and $H$ TA $(\boldsymbol{E}-\boldsymbol{H})$ were determined by analyzing single video frames from recordings of beam walking of mice before injury $(\boldsymbol{A}, \boldsymbol{E}), 1$ week $(\boldsymbol{B}, \boldsymbol{F})$ and 4 months $(\boldsymbol{C}, \boldsymbol{D}, \boldsymbol{G}, \boldsymbol{H})$ after injury and application of histone $\mathrm{H} 1(\boldsymbol{B}, \boldsymbol{D}, \boldsymbol{F}, \boldsymbol{H})$ or PBS as vehicle solution $(\boldsymbol{C}, \boldsymbol{G})$ to the lesion site. $\mathbf{I}-\mathbf{L}$, Time course of motor recovery after application of histone $H 1$ or PBS are shown as mean values \pm SEM of foot-base angle $(\boldsymbol{I})$ and heels-tail angle $(\boldsymbol{J})$, protraction length ratio $(\boldsymbol{K})$, and stance recovery index $(\boldsymbol{L})$ at different time indicated in the graphs. Numbers of animals studied per group are indicated in brackets. The asterisks indicate significant differences ( $p<0.05$, one-way ANOVA with Tukey's post hoc test) between the histone H1-treated group and the PBS control group at the given time points.

best days after application because of its degradation, the question arises how a single application of histone $\mathrm{H} 1$ to the lesion site produces this late-appearing and long-lasting conducive effect of this protein. We propose that histone $\mathrm{H} 1$ modulates early cellular and molecular responses to injury such that subsequent regeneration processes are positively influenced over weeks. Interaction of histone $\mathrm{H} 1$ with its cell surface receptors (e.g., PSA-NCAM) may trigger signal transduction events that alter gene expression in Schwann cells and/or neurons resulting, for example, in inhibition of the expression of factors involved in neurodegeneration and/or in induction or enhancement of the expression of factors, such as cell surface receptors, growth factors, or metabolic en- 

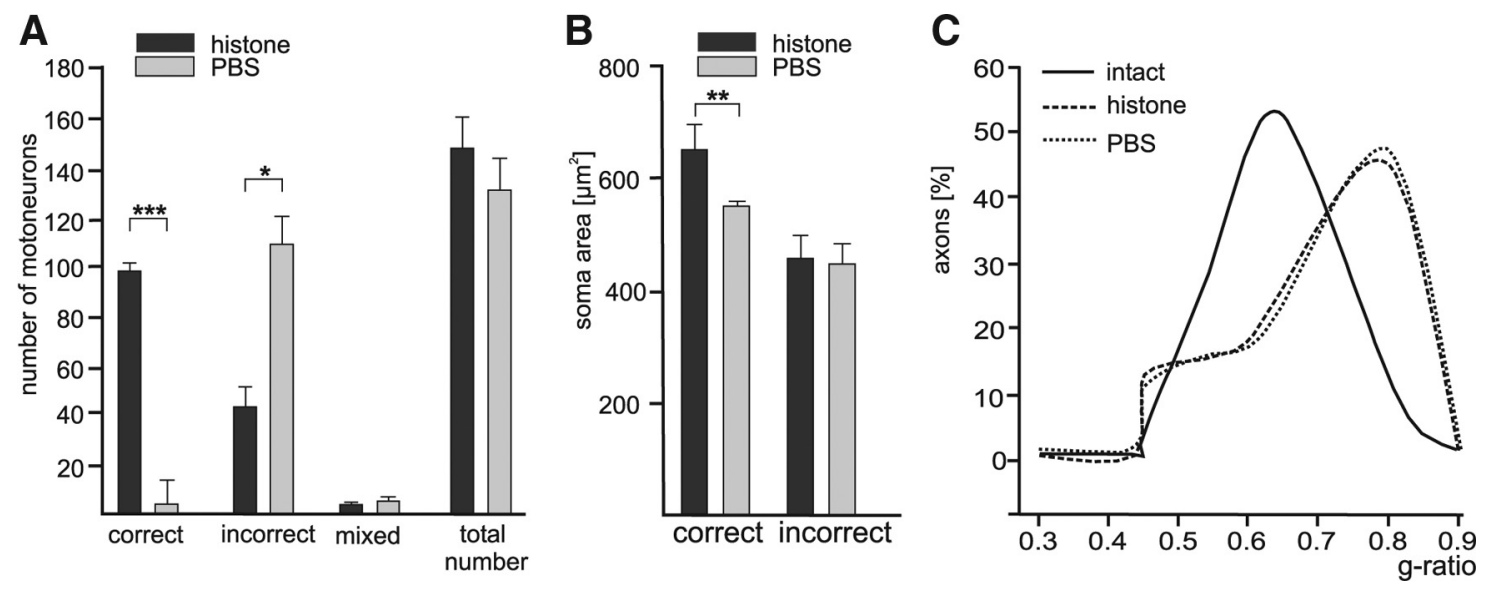

Figure 9. Analysis of regrowth of motoneuron axons after femoral nerve injury. Four months after injury and application of histone $\mathrm{H} 1$ or vehicle (PBS), animals were subjected to retrograde labeling of motoneurons. A, Mean numbers + SEM of motoneurons labeled through the motor branch representing correctly projecting neurons (correct), through the sensory branch representing incorrectly projecting neurons (incorrect), through both branches (mixed), and the sum of labeled neurons (total number) are shown. $\boldsymbol{B}$, Morphometric analysis of soma size of regenerated motoneurons was performed. Mean values + SEM of soma area of correctly and incorrectly projecting motoneurons after application of histone $\mathrm{H} 1$ or PBS are shown. $A, B$, Significant differences between the groups of eight animals are indicated by asterisks ( ${ }^{*} p<0.05$, ${ }^{* *} p<0.01$, ${ }^{* * *} p<0.001$, one-way ANOVA with Tukey's post hoc test). $C$, Analysis of myelinated nerve fibers in regenerated and intact nerves. Shown are normalized frequency distributions of $\mathrm{g}$ ratios (axon/fiber diameter) in the motor nerve branch of noninjured mice (intact) and mice treated with histone H1 (histone) or vehicle (PBS) 4 months after injury.

zymes that generate long-lasting beneficial and positive effects on neuronal survival and neurite regrowth and thus on functional recovery and regeneration. Since histone $\mathrm{H} 1$ can penetrate through the plasma membrane (Hariton-Gazal et al., 2003), it is conceivable that extracellular histone $\mathrm{H} 1$ directly affects gene regulation after translocation into the cell and import into the nucleus. It is also conceivable that PSA may facilitate or enhance the translocation of histone $\mathrm{H} 1$ through the plasma membrane. Based on our in vitro data of enhanced proliferation and process elongation of Schwann cells, we propose that histone H1 stimulates an early response of these cells to injury resulting in priming the injured femoral nerve at the lesion site to regenerate. Recently, it has been shown that the communication between Schwann cells and regrowing motoneurons plays a crucial in regeneration (Vrbova et al., 2009). Since neurite outgrowth in vitro was promoted by histone $\mathrm{H} 1$, we consider it likely that regeneration of the injured nerve elicited by histone $\mathrm{H} 1$ is, at least in part, because of enhanced axonal regrowth in vivo. Indeed, retrograde labeling of motoneurons demonstrated enhanced axonal regrowth and precision of appropriate reinnervation of the correct branch of the femoral nerve when compared with controls. It is interesting, in this respect, that brief low-frequency electrical stimulation of the injured femoral nerve, which also leads to long-lasting enhancement of axonal regrowth (Al-Majed et al., 2000; Brushart et al., 2005) and functional recovery (Ahlborn et al., 2007), is associated with an upregulation in BDNF expression, which is a PSA binding partner (Kanato et al., 2008) that promotes neuronal survival and differentiation during development (for instance, see Sofroniew et al., 2001) and that is required for myelination and regeneration of injured sciatic nerve (Zhang et al., 2000).

The diverse and, importantly, long-lasting effects of the histone $\mathrm{H} 1$ treatment suggest its involvement in basic signaling mechanisms that are most likely PSA-dependent, but may be also PSA-independent. PSA, which is N-glycosidically linked to NCAM, acts as a positive modulator of NCAM functions by inhibiting the cis-interactions of NCAM and thus making more NCAM available for trans-interactions (Doherty et al., 1990; Lüthl et al., 1994; Doherty and Walsh, 1996; Muller et al., 1996) with, for instance, L1 and proteoglycans. It has been proposed that the PSA-mimicking peptide, which improves regeneration and myelination of injured femoral nerve but influences neither motoneuron regrowth nor preferential reinnervation (Mehanna et al., 2009), interferes with inhibitory interactions between PSANCAM and its receptor(s) and thereby could affect signaling pathways and lead to the observed in vivo effects. Fibroblast growth factor receptors (FGFRs), which are involved in NCAM signaling (Kiselyov et al., 2003), are likely mediators of PSAinduced signal pathways that affect myelination, since FGFRs are expressed on Schwann cells (Grothe et al., 2001) and are involved in myelination (Ogata et al., 2004). Furthermore, levels of FGFRs are increased in Schwann cells after sciatic nerve injury (Grothe et al., 2001) and mice deficient in FGFR-3 showed reduced myelin thickness compared with wild-type controls (Jungnickel et al., 2004). Since myelination was not improved by application of histone $\mathrm{H} 1$, whereas preferential reinnervation and axonal regrowth was enhanced, we assume that binding of histone $\mathrm{H} 1$ to PSA-NCAM activates other signal pathways than the PSAmimicking peptide. These yet-unknown PSA-dependent or PSAindependent signal transduction pathways or mechanisms could trigger axonal regrowth and correct reinnervation, but not remyelination. However, the interaction of histone $\mathrm{H} 1$ with PSA binding partners, such as heparan sulfate proteoglycans, which promote axonal growth and synaptic plasticity in a PSA-dependent manner (Storms and Rutishauser, 1998; Dityatev et al., 2004), may modulate the interaction between PSA and other binding molecules, such as BDNF and, thus, may influence PSA-induced signal transduction pathways.

The functions of histone $\mathrm{H} 1$ on different neural cell types and its interaction with different binding partners show that it plays a central role in modulating and integrating various cellular functions associated with cell survival, proliferation, and regeneration in a PSA-dependent or possibly PSA-independent manner. Our results reveal that histone $\mathrm{H} 1$ has beneficial effects in regeneration in the mouse peripheral nervous system and indicate a promising therapeutic potential for treatment of peripheral nerve injuries in humans. 


\section{References}

Ahlborn P, Schachner M, Irintchev A (2007) One hour electrical stimulation accelerates functional recovery after femoral nerve repair. Exp Neurol 208:137-144.

Al-Majed AA, Neumann CM, Brushart TM, Gordon T (2000) Brief electrical stimulation promotes the speed and accuracy of motor axonal regeneration. J Neurosci 20:2602-2608.

Angata K, Huckaby V, Ranscht B, Terskikh A, Marth JD, Fukuda M (2007) Polysialic acid-directed migration and differentiation of neural precursors are essential for mouse brain development. Mol Cell Biol 27:6659-6668.

Asahara T, Lin M, Kumazawa Y, Takeo K, Akamine T, Nishimura Y, Kayahara T, Yamamoto T (1999) Long-term observation on the changes of somatotopy in the facial nucleus after nerve suture in the cat: morphological studies using retrograde labeling. Brain Res Bull 49:195-202.

Bolton SJ, Perry VH (1997) Histone H1; a neuronal protein that binds bacterial lipopolysaccharide. J Neurocytol 26:823-831.

Brix K, Summa W, Lottspeich F, Herzog V (1998) Extracellularly occurring histone $\mathrm{H} 1$ mediates the binding of thyroglobulin to the cell surface of mouse macrophages. J Clin Invest 102:283-293.

Brushart TM (1988) Preferential reinnervation of motor nerves by regenerating motor axons. J Neurosci 8:1026-1031.

Brushart TM, Jari R, Verge V, Rohde C, Gordon T (2005) Electrical stimulation restores the specificity of sensory axon regeneration. Exp Neurol 194:221-229.

Carratù MR, Labate M, De Santis S, Lacomba C, Cuomo V (1993) Upregulation of polysialic acid in peripheral myelinated axons of rat chronically exposed to 2,5-hexanedione. Pharmacol Toxicol 72:236-239.

Chazal G, Durbec P, Jankovski A, Rougon G, Cremer H (2000) Consequences of neural cell adhesion molecule deficiency on cell migration in the rostral migratory stream of the mouse. J Neurosci 20:1446-1457.

Cohen RS, Blomberg F, Berzins K, Siekevitz P (1977) The structure of postsynaptic densities isolated from dog cerebral cortex. J Cell Biol 74:181-203.

Curreli S, Arany Z, Gerardy-Schahn R, Mann D, Stamatos NM (2007) Polysialylated neuropilin-2 is expressed on the surface of human dendritic cells and modulates dendritic cell-T lymphocyte interactions. J Biol Chem 282:30346-30356.

Decker L, Avellana-Adalid V, Nait-Oumesmar B, Durbec P, Baron-Van Evercooren A (2000) Oligodendrocyte precursor migration and differentiation: combined effects of PSA residues, growth factors, and substrates. Mol Cell Neurosci 16:422-439.

de la Cruz RR, Pastor AM, Delgado-García JM (1994) Effects of target depletion on adult mammalian central neurons: morphological correlates. Neuroscience 58:59-79.

Dihné M, Bernreuther C, Sibbe M, Paulus W, Schachner M (2003) A new role for the cell adhesion molecule L1 in neural precursor cell proliferation, differentiation, and transmitter-specific subtype generation. J Neurosci 23:6638-6650.

Dityatev A, Dityateva G, Sytnyk V, Delling M, Toni N, Nikonenko I, Muller D, Schachner M (2004) Polysialylated neural cell adhesion molecule promotes remodeling and formation of hippocampal synapses. J Neurosci 24:9372-9382.

Doenecke D, Albig W, Bode C, Drabent B, Franke K, Gavenis K, Witt O (1997) Histones: genetic diversity and tissue-specific gene expression. Histochem Cell Biol 107:1-10.

Doherty P, Walsh FS (1996) CAM-FGF receptor interactions: a model for axonal growth. Mol Cell Neurosci 8:99-111.

Doherty P, Cohen J, Walsh FS (1990) Neurite outgrowth in response to transfected N-CAM changes during development and is modulated by polysialic acid. Neuron 5:209-219.

Duce JA, Smith DP, Blake RE, Crouch PJ, Li QX, Masters CL, Trounce IA (2006) Linker histone $\mathrm{H} 1$ binds to disease associated amyloid-like fibrils. J Mol Biol 361:493-505.

Evans SV, Sigurskjold BW, Jennings HJ, Brisson JR, To R, Tse WC, Altman E, Frosch M, Weisgerber C, Kratzin HD (1995) Evidence for the extended helical nature of polysaccharide epitopes. The $2.8 \AA$ resolution structure and thermodynamics of ligand binding of an antigen binding fragment specific for alpha- $(2 \rightarrow 8)$-polysialic acid. Biochemistry 34:6737-6744.

Franz CK, Rutishauser U, Rafuse VF (2005) Polysialylated neural cell adhesion molecule is necessary for selective targeting of regenerating motor neurons. J Neurosci 25:2081-2091.
Frosch M, Görgen I, Boulnois GJ, Timmis KN, Bitter-Suermann D (1985) NZB mouse system for production of monoclonal antibodies to weak bacterial antigens: isolation of an IgG antibody to the polysaccharide capsules of Escherichia coli K1 and group B meningococci. Proc Natl Acad Sci U S A 82:1194-1198.

Garcia-Segura LM, Cañas B, Parducz A, Rougon G, Theodosis D, Naftolin F, Torres-Aleman I (1995) Estradiol promotion of changes in the morphology of astroglia growing in culture depends on the expression of polysialic acid of neural membranes. Glia 13:209-216.

Griffiths AD, Williams SC, Hartley O, Tomlinson IM, Waterhouse P, Crosby WL, Kontermann RE, Jones PT, Low NM, Allison TJ (1994) Isolation of high affinity human antibodies directly from large synthetic repertoires. EMBO J 13:3245-3260.

Grothe C, Meisinger C, Claus P (2001) In vivo expression and localization of the fibroblast growth factor system in the intact and lesioned rat peripheral nerve and spinal ganglia. J Comp Neurol 434:342-357.

Guseva D, Angelov DN, Irintchev A, Schachner M (2009) Ablation of adhesion molecule L1 in mice favours Schwann cell proliferation and functional recovery after peripheral nerve injury. Brain 132:2180-2195.

Hammond MS, Sims C, Parameshwaran K, Suppiramaniam V, Schachner M, Dityatev A (2006) Neural cell adhesion molecule-associated polysialic acid inhibits NR2B-containing $N$-methyl-D-aspartate receptors and prevents glutamate-induced cell death. J Biol Chem 281:34859-34869.

Hampton RY, Golenbock DT, Raetz CR (1988) Lipid A binding sites in membranes of macrophage tumor cells. J Biol Chem 263:14802-14807.

Hariton-Gazal E, Rosenbluh J, Graessmann A, Gilon C, Loyter A (2003) Direct translocation of histone molecules across cell membranes. J Cell Sci 116:4577-4586.

Henriquez JP, Casar JC, Fuentealba L, Carey DJ, Brandan E (2002) Extracellular matrix histone $\mathrm{H} 1$ binds to perlecan, is present in regenerating skeletal muscle and stimulates myoblast proliferation. J Cell Sci 115:2041-2051.

Holers VM, Kotzin BL (1985) Human peripheral blood monocytes display surface antigens recognized by monoclonal antinuclear antibodies. J Clin Invest 76:991-998.

Holliger P, Prospero T, Winter G (1993) "Diabodies": small bivalent and bispecific antibody fragments. Proc Natl Acad Sci U S A 90:6444-6448.

$\mathrm{Hu} \mathrm{H}$ (2000) Polysialic acid regulates chain formation by migrating olfactory interneuron precursors. J Neurosci Res 61:480-492.

Hu H, Tomasiewicz H, Magnuson T, Rutishauser U (1996) The role of polysialic acid in migration of olfactory bulb interneuron precursors in the subventricular zone. Neuron 16:735-743.

Jungnickel J, Gransalke K, Timmer M, Grothe C (2004) Fibroblast growth factor receptor 3 signaling regulates injury-related effects in the peripheral nervous system. Mol Cell Neurosci 25:21-29.

Jungnickel J, Brämer C, Bronzlik P, Lipokatic-Takacs E, Weinhold B, Gerardy-Schahn R, Grothe C (2009) Level and localization of polysialic acid is critical for early peripheral nerve regeneration. Mol Cell Neurosci 40:374-381.

Kanato Y, Kitajima K, Sato C (2008) Direct binding of polysialic acid to a brain-derived neurotrophic factor depends on the degree of polymerization. Glycobiology 18:1044-1053.

Kiselyov VV, Skladchikova G, Hinsby AM, Jensen PH, Kulahin N, Soroka V, Pedersen N, Tsetlin V, Poulsen FM, Berezin V, Bock E (2003) Structural basis for a direct interaction between FGFR1 and NCAM and evidence for a regulatory role of ATP. Structure 11:691-701.

Kleene R, Schachner M (2004) Glycans and neural cell interactions. Nat Rev Neurosci 5:195-208.

Kruse J, Mailhammer R, Wernecke H, Faissner A, Sommer I, Goridis C, Schachner M (1984) Neural cell adhesion molecules and myelinassociated glycoprotein share a common carbohydrate moiety recognized by monoclonal antibodies L2 and HNK-1. Nature 311:153-155.

Lüthl A, Laurent JP, Figurov A, Muller D, Schachner M (1994) Hippocampal long-term potentiation and neural cell adhesion molecules L1 and NCAM. Nature 372:777-779.

Makhina T, Loers G, Schulze C, Ueberle B, Schachner M, Kleene R (2009) Extracellular GAPDH binds to L1 and enhances neurite outgrowth. Mol Cell Neurosci 41:206-218.

Marino P, Norreel JC, Schachner M, Rougon G, Amoureux MC (2009) A polysialic acid mimetic peptide promotes functional recovery in a mouse model of spinal cord injury. Exp Neurol 219:163-174.

Mehanna A, Mishra B, Kurschat N, Schulze C, Bian S, Loers G, Irintchev A, 
Schachner M (2009) Polysialic acid glycomimetics promote myelination and functional recovery after peripheral nerve injury in mice. Brain 132:1449-1462.

Mehanna A, Jakovcevski I, Acar A, Xiao M, Loers G, Rougon G, Irintchev A, Schachner M (2010) Polysialic acid glycomimetic promotes functional recovery and plasticity after spinal cord injury in mice. Mol Ther $18: 34-43$.

Mühlenhoff M, Eckhardt M, Gerardy-Schahn R (1998) Polysialic acid: three-dimensional structure, biosynthesis and function. Curr Opin Struct Biol 8:558-564.

Muller D, Wang C, Skibo G, Toni N, Cremer H, Calaora V, Rougon G, Kiss JZ (1996) PSA-NCAM is required for activity-induced synaptic plasticity. Neuron 17:413-422.

Muller D, Djebbara-Hannas Z, Jourdain P, Vutskits L, Durbec P, Rougon G, Kiss JZ (2000) Brain-derived neurotrophic factor restores long-term potentiation in polysialic acid-neural cell adhesion molecule-deficient hippocampus. Proc Natl Acad Sci U S A 97:4315-4320.

Ogata T, Iijima S, Hoshikawa S, Miura T, Yamamoto S, Oda H, Nakamura K, Tanaka S (2004) Opposing extracellular signal-regulated kinase and Akt pathways control Schwann cell myelination. J Neurosci 24:6724-6732.

Olsen M, Zuber C, Roth J, Linnemann D, Bock E (1995) The ability to re-express polysialylated NCAM in soleus muscle after denervation is reduced in aged rats compared to young adult rats. Int J Dev Neurosci 13:97-104.

Papastefanaki F, Chen J, Lavdas AA, Thomaidou D, Schachner M, Matsas R (2007) Grafts of Schwann cells engineered to express PSA-NCAM promote functional recovery after spinal cord injury. Brain 130:2159-2174.

Parseghian MH, Luhrs KA (2006) Beyond the walls of the nucleus: the role of histones in cellular signaling and innate immunity. Biochem Cell Biol 84:589-604.

Patrzykat A, Zhang L, Mendoza V, Iwama GK, Hancock RE (2001) Synergy of histone-derived peptides of coho salmon with lysozyme and flounder pleurocidin. Antimicrob Agents Chemother 45:1337-1342.
Potempska A, Ramakrishna N, Wisniewski HM, Miller DL (1993) Interaction between the beta-amyloid peptide precursor and histones. Arch Biochem Biophys 304:448-453.

Rutishauser U (2008) Polysialic acid in the plasticity of the developing and adult vertebrate nervous system. Nat Rev Neurosci 9:26-35.

Simova O, Irintchev A, Mehanna A, Liu J, Dihné M, Bächle D, Sewald N, Loers G, Schachner M (2006) Carbohydrate mimics promote functional recovery after peripheral nerve repair. Ann Neurol 60:430-437.

Sofroniew MV, Howe CL, Mobley WC (2001) Nerve growth factor signaling, neuroprotection, and neural repair. Annu Rev Neurosci 24:12171281.

Storms SD, Rutishauser U (1998) A role for polysialic acid in neural cell adhesion molecule heterophilic binding to proteoglycans. J Biol Chem 273:27124-27129.

Vaithianathan T, Matthias K, Bahr B, Schachner M, Suppiramaniam V, Dityatev A, Steinhaüser C (2004) Neural cell adhesion moleculeassociated polysialic acid potentiates AMPA receptor currents. J Biol Chem 279:47975-47984.

Vrbova G, Mehra N, Shanmuganathan H, Tyreman N, Schachner M, Gordon $\mathrm{T}$ (2009) Chemical communication between regenerating motor axons and Schwann cells in the growth pathway. Eur J Neurosci 30:366-375.

Waters HJ, Barnett G, O’Hanlon GM, Lowrie MB (1998) Motoneuron survival after neonatal peroneal nerve injury in the rat-evidence for the sparing effect of reciprocal inhibition. Exp Neurol 152:95-100.

Watson K, Edwards RJ, Shaunak S, Parmelee DC, Sarraf C, Gooderham NJ, Davies DS (1995) Extra-nuclear location of histones in activated human peripheral blood lymphocytes and cultured T-cells. Biochem Pharmacol 50:299-309.

Watson K, Gooderham NJ, Davies DS, Edwards RJ (1999) Nucleosomes bind to cell surface proteoglycans. J Biol Chem 274:21707-21713.

Zhang JY, Luo XG, Xian CJ, Liu ZH, Zhou XF (2000) Endogenous BDNF is required for myelination and regeneration of injured sciatic nerve in rodents. Eur J Neurosci 12:4171-4180. 